Discussion Paper No. 15-014

Taxing Investments in the Asia-Pacific Region:

The Importance of Cross-Border Taxation and Tax Incentives

Verena Wiedemann and Katharina Finke

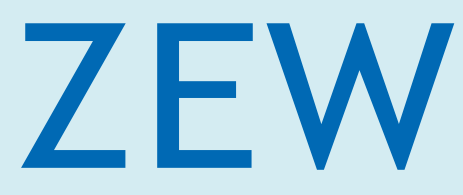

Zentrum für Europäische Wirtschaftsforschung $\mathrm{GmbH}$ Centre for European Economic Research 
Discussion Paper No. 15-014

\title{
Taxing Investments in the Asia-Pacific Region: The Importance of Cross-Border Taxation and Tax Incentives
}

\author{
Verena Wiedemann and Katharina Finke
}

Download this ZEW Discussion Paper from our ftp server:

http://ftp.zew.de/pub/zew-docs/dp/dp15014.pdf

Die Discussion Papers dienen einer möglichst schnellen Verbreitung von neueren Forschungsarbeiten des ZEW. Die Beiträge liegen in alleiniger Verantwortung der Autoren und stellen nicht notwendigerweise die Meinung des ZEW dar.

Discussion Papers are intended to make results of ZEW research promptly available to other economists in order to encourage discussion and suggestions for revisions. The authors are solely responsible for the contents which do not necessarily represent the opinion of the ZEW. 


\title{
Taxing investments in the Asia-Pacific region: The importance of cross-border taxation and tax incentives
}

\author{
Verena Wiedemann * \\ Katharina Finke (ZEW and University of Mannheim) ${ }^{+}$
}

February 2015

\begin{abstract}
This paper investigates the taxation of investments in the Asia-Pacific region. Our analysis is based on the methodology of Devereux and Griffith $(1999,2003)$ for determining effective average tax rates. This approach allows us to account for important national and international tax regulations. Our results show that the overall dispersion of effective tax burdens in Asia-Pacific ranges from 10.6\% in Hong

Kong to $40.4 \%$ in India for domestic investments (overall average of 23.4\%). In 8 out of 19 jurisdictions covered, investments are, however, effectively taxed at a rate between $20 \%$ and $25 \%$. If the investment is made by a foreign investor, cross-border taxation has a significant impact on the

overall tax burden. In any of the Asia-Pacific jurisdictions, foreign direct investments by a

Singaporean or a German parent company are on average taxed at $29.2 \%$ and at $32.8 \%$ in case of a US investor. Meanwhile, tax incentives for the stimulation of private investment reduce the effective average tax rate by 8.6 percentage points on average. Fiscal incentives targeted at investments in the high technology sector or the development of specific geographic areas result in the lowest effective tax burdens.
\end{abstract}

Keywords: Corporate Taxation, Effective Average Tax Rate, Tax Incentives, Asia

* This paper was prepared while the author was working at ZEW as student research assistant.

+ ZEW and University of Mannheim; finke@zew.de 


\section{Introduction}

Between 2000 and 2012 the Gross Domestic Product (GDP) of economies in the Asia-Pacific region grew at a rate of $5.56 \%$ p.a. on average, ${ }^{1}$ leaving all other regions in the world well behind in terms of growth. ${ }^{2}$ Today, the region still experiences economic transformations, with many developing countries heading for their next stage of development and new countries calling the world's attention. The objective of China's latest Five-Year Plan to increase the country's minimum wage standard by $13 \%$ on average each year ${ }^{3}$ as well as capacities being shifted towards the high-end manufacturing sector, ${ }^{4}$ both have significant implications for the country's economy. According to the most recent World Investment Report, high technology industries in China now attract both foreign and domestic investment and the country's economy is involved in more advanced activities of the value chain. ${ }^{5}$ While production costs in China are rising, labour-intensive industries move southward to countries like Vietnam and Cambodia. ${ }^{6}$ Other countries such as Mongolia, Laos and Myanmar have recently attracted foreign investment mainly because of natural resources. ${ }^{7}$ Between 2010 and 2012, foreign direct investment (FDI) into Myanmar and Mongolia increased by $175 \%$ and $260 \%$ respectively, while FDI into Cambodia doubled within those two years. ${ }^{8}$ Moreover, as a major step towards more regional integration, the ten member-states of the Association of Southeast Asian Nations (ASEAN) will form the ASEAN Economic Community (AEC), by $2015 .^{9}$

Against the background of these developments this paper takes a closer look at taxation of private investments in Asia-Pacific countries. Among other aspects, such as the country's legal framework, infrastructure, market access and labour costs, taxes are regarded as one influential factor of investment decisions. ${ }^{10}$ Various studies provide evidence on the responsiveness of FDI to changes in the tax burden. ${ }^{11}$ Devereux and Griffith (2003) argue that discrete investment choices, such as location decisions, depend on effective average tax burdens. In their meta-study Feld and Heckemeyer (2010) reveal that an investment's sensitivity to effective tax rates capturing bilateral taxation is substantially higher compared to the statutory tax rate and effective tax rates at the unilateral level.

We will therefore consider effective tax rates to investigate the tax burden of investments in the Asia-Pacific region. Besides the corporate income tax rate, depreciation rules, non-income taxes and other features of the national tax code and international tax treaties affect the effective tax burden of an investment. To account for these factors, this paper makes use of an

\footnotetext{
${ }^{1}$ This figure combines annual growth rates of all countries covered in this paper. See below.

${ }^{2}$ World Bank Open Data (2014) average annual \% growth of GDP. Worldwide GDP grew by 2.7 \% p.a. during the same period of time.

${ }^{3}$ See Deng (2011) available at http://news.xinhuanet.com/english2010/china/2011-03/05/c_13762230.htm.

${ }^{4}$ See IMF (2012) pp. $37 \mathrm{f}$.

${ }^{5}$ See UNCTAD (2013) p. 46.

${ }^{6}$ See UNCTAD (2013) p. 46.

${ }^{7}$ See UNCTAD (2013) pp. $46 \mathrm{f}$ and IMF (2012).

${ }^{8}$ See UNCTAD (2013) p. 214.

${ }^{9}$ See ASEAN Secretariat and World Bank (2013) p. i.

${ }^{10}$ See OECD (2007) p.77.

${ }^{11}$ Meta-studies by De Mooij/Ederveen (2003) and Feld/Heckemeyer (2011) analyse the results of previous research on this topic.
} 
approach developed by Devereux and Griffith (1999). Based on their methodology, we compute the tax burden on domestic investments and outbound investments by a parent company from Germany, Singapore and the United States in selected Asia-Pacific countries. In order to stimulate investment in certain activities or industries, countries in the Asia-Pacific region, especially the ASEAN countries, rely on tax incentives. Therefore we will take a closer look at the impact such incentives have on an investment's tax burden. The following analysis covers Australia, Cambodia, China, Hong Kong SAR, India, Indonesia, Japan, Lao PR, Malaysia, Mongolia, Myanmar, New Zealand, the Philippines, the Republic of Korea, Russia, Singapore, Taiwan Province of China, Thailand and Vietnam. ${ }^{12}$

The remainder of the paper is structured as follows: In section 1 the methodology applied and the underlying tax regimes of countries in the Asia-Pacific region are introduced. Based on those parameters, we then calculate the EATR for domestic investments in Asia-Pacific countries and cross-border outbound investments undertaken by parent companies from Germany, Singapore and the United States (US). In section 4 we further assess the impact of tax incentives on the effective tax burden. The last section summarizes the findings.

\section{Methodology and Underlying Tax Regimes}

\subsection{Methodology and Assumptions}

When evaluating the impact of taxation on investment choices, effective tax rates play an important role. Widely recognized measures of effective tax levels include the effective marginal tax rate (EMTR) by King and Fullerton (1984) and the effective average tax rate (EATR) by Devereux and Griffith (1999 and 2003). These forward-looking approaches are particularly suited for estimating the effect of taxation on future investment decisions, as they assume a hypothetical investment and estimate tax payments associated with this particular decision. Besides statutory tax rates they incorporate important tax base regulations and nonprofit taxes. Both measures have already been applied in numerous international studies (e.g. European Commission (2002 and 2013)). The intuition behind both approaches is to identify the relative wedge between pre- and post-tax values of the investment in a consistent framework. In the context of multinational firms' location choices, the EATR has proved to be the most relevant to depict the respective tax attractiveness of potential host countries of FDI. $^{13}$

The EATR can be calculated in a domestic setting, taking only the local tax system into account, and internationally, by incorporating withholding taxes and the treatment of crossborder dividends or interests in the investor's residence country.

Our analysis considers an investor undertaking a manufacturing project located in the AsiaPacific region. The firm equally invests in five different assets, namely intangibles acquired from third parties, industrial buildings, machinery, financial assets, and inventory. As our

\footnotetext{
${ }^{12}$ In the following the Hong Kong SAR is referred to as Hong Kong; Lao PR as Laos; the Republic of Korea as South Korea and Taiwan Province of China as Taiwan. The term Taiwan Province of China corresponds to the official terminology adopted by the International Monetary Fund (IMF) and the United Nations in order to refer to the territory of the island of Taiwan. This paper covers the majority of the countries that belong to the Asia and Pacific region as defined by the IMF: https://www.imf.org/external/oap/about.htm

${ }^{13}$ See Devereux/Griffith 2003.
} 
focus will be on the effects of taxation, other economic factors such as inflation and real economic depreciations are held constant. Our assumptions on these variables are in line with other studies that apply the same methodology and are presented in Table A1 in the appendix. For explanations on how to include debt financing, capital taxes, valuation methods and other common features of tax systems see European Commission (2013). The methodology is discussed in greater detail in Devereux and Griffith (1999 and 2003) as well as in Schreiber, Spengel and Lammersen (2002).

\subsection{Tax Regimes in the Asia-Pacific Region}

The computation of the EATR is based on significant features of the respective country's tax system (e.g. depreciation allowances, profit and non-profit tax rates). Hence, we briefly survey the tax regimes in the considered territories.

In line with global trends to cut corporate income tax rates, Singapore, Malaysia, South Korea and India have steadily reduced their tax rates since the early $1990 \mathrm{~s}^{14}{ }^{14}$ In most other countries tax rates remained rather stable until just recently. ${ }^{15}$ Starting with China in 2008 these territories cut their rates, sometimes by as much as 10 percentage points within two years as Thailand did in 2012/13. Having reduced its corporate income tax rate from 25\% to $22 \%$ in 2014, Vietnam already announced a further reduction down to $20 \%$ for 2016 . Nowadays the vast majority of the countries levy corporate income tax rates of $20 \%$ to $25 \%$. The average rate of all territories in the Asia-Pacific region also amounts to 25\%. The lowest tax rate imposed on profits is at $15 \%$ in Hong Kong, while India is leading the high tax countries in the region with a tax rate of $45.2 \%$ imposed on distributed profits. Whereas the tax rate on retained earnings is only at $34 \%$ in India, the opposite is true for Taiwan which levies $17 \%$ on distributed profits but demands $25.3 \%$ for retained ones. Table A2 in the appendix gives an overview of nominal and combined statutory tax rates, which include surcharges and local business taxes, for jurisdictions in the Asia-Pacific region.

Besides taxing income from business activities, corporations can also be subject to nonincome taxes such as property tax on one or all business assets. In all countries covered these taxes are deductible from corporate income tax. Therefore the effective tax burden differs from nominal tax rates. ${ }^{16}$

When computing the tax base, depreciation rules and valuation methods of assets in use have to be considered. Buildings and intangibles have to be depreciated on a straight-line basis in most countries. Singapore, however, entirely prohibits the depreciation of industrial buildings and acquired intangible assets. For machinery the most common pattern is the declining balance method. However, in most cases straight-line depreciation is allowed as well. If two or more depreciation schedules are available, we employ the one resulting in the lowest tax burden when computing the tax base. Table A4 in the appendix summarizes the durations, depreciation rates and valuation methods applied in our analysis.

Only six countries in Asia-Pacific permit corporations to value their inventory using the lastin-first-out (LIFO) method. If applied, this method results in the lowest tax burden. Everywhere else, the most favourable method allowed is a valuation based on weighted

\footnotetext{
${ }^{14}$ See Endres, Fuest, Spengel et al. (2010) pp. $65 \mathrm{f}$.

${ }^{15}$ See Endres, Fuest, Spengel et al. (2010) pp. $65 \mathrm{f}$.

${ }^{16}$ For details on the respective nominal and real tax rates on property and real estate see Table A3.
} 
averages. Furthermore, in some countries interest paid by a corporation cannot be fully deducted when computing the tax base. This is the case for the tax base of the local business tax in the Philippines and a surcharge on the so-called business scale enterprise tax in Japan. ${ }^{17}$ In Hong Kong we find the reversed situation. Interest payments received by a non-financial institution from a deposit in Hong Kong are exempt from profit tax. In our model this regulation affects the taxation of financial assets.

\section{Effective Average Tax Rates for Domestic and Cross-Border Investments in the Asia-Pacific Region}

\subsection{Effective Average Tax Rates for Domestic Investments}

Based on parameters of the national tax codes that have been discussed above, it is now possible to assess the EATR for investments in the covered jurisdictions. As a first step we now consider domestic investments or investments at the subsidiary level.

Our results, displayed in Figure 1, show that the effective tax burden is on average 1.63 percentage points lower than the combined statutory tax rate. The overall dispersion of EATRs in the Asia-Pacific region is quite substantial ranging from $10.6 \%$ in Hong Kong to $40.4 \%$ in India. It is, however, striking that 12 out of 19 countries tax investments at an effective rate between $15 \%$ and $25 \%$. This result is mainly driven by similar statutory tax rates applied by these jurisdictions. With the exception of Singapore, an EATR of 15\% to $25 \%$ goes in line with a statutory tax rate of $20 \%$ to $25 \%$. Hence, for purely domestic investments these countries offer quite a level playing field in terms of taxation.

Very generous depreciation patterns in Hong Kong and Laos (EATR of 21.1\%) lead to EATRs that are 6 and 3 points respectively lower than the corporate income tax rate of the national tax code. The opposite effect can be observed in Singapore, where depreciation of industrial buildings and acquired intangibles has been abandoned for tax purposes. These regulations result in an EATR of $18.6 \%$ exceeding the statutory tax rate of $17 \%$ on investments in Singapore. Therefore, investors in Cambodia, Taiwan and Thailand face lower effective tax burdens, although statutory tax rates of these territories are higher than in Singapore. In the case of Japan, multiple non-income tax rates lead to an EATR that exceeds the combined statutory tax rate by 1.7 percentage points. Since we assume that only $10 \%$ of the investment is financed by new equity, the impact of the $15 \%$ dividend distribution tax on the EATR in India is limited. The EATR for an investment in India is at $40.4 \%$ compared to a corporate income tax of $45.2 \%$ on distributed profits.

\footnotetext{
${ }^{17}$ This tax is included in the $20.7 \%$ surcharge in Table A2. For details on the Japanese corporate tax system and the multiple surcharges imposed see Tax Research Platform of the IBFD.
} 
Figure 1 - Comparison of EATRs and statutory tax rates of Asia-Pacific jurisdictions

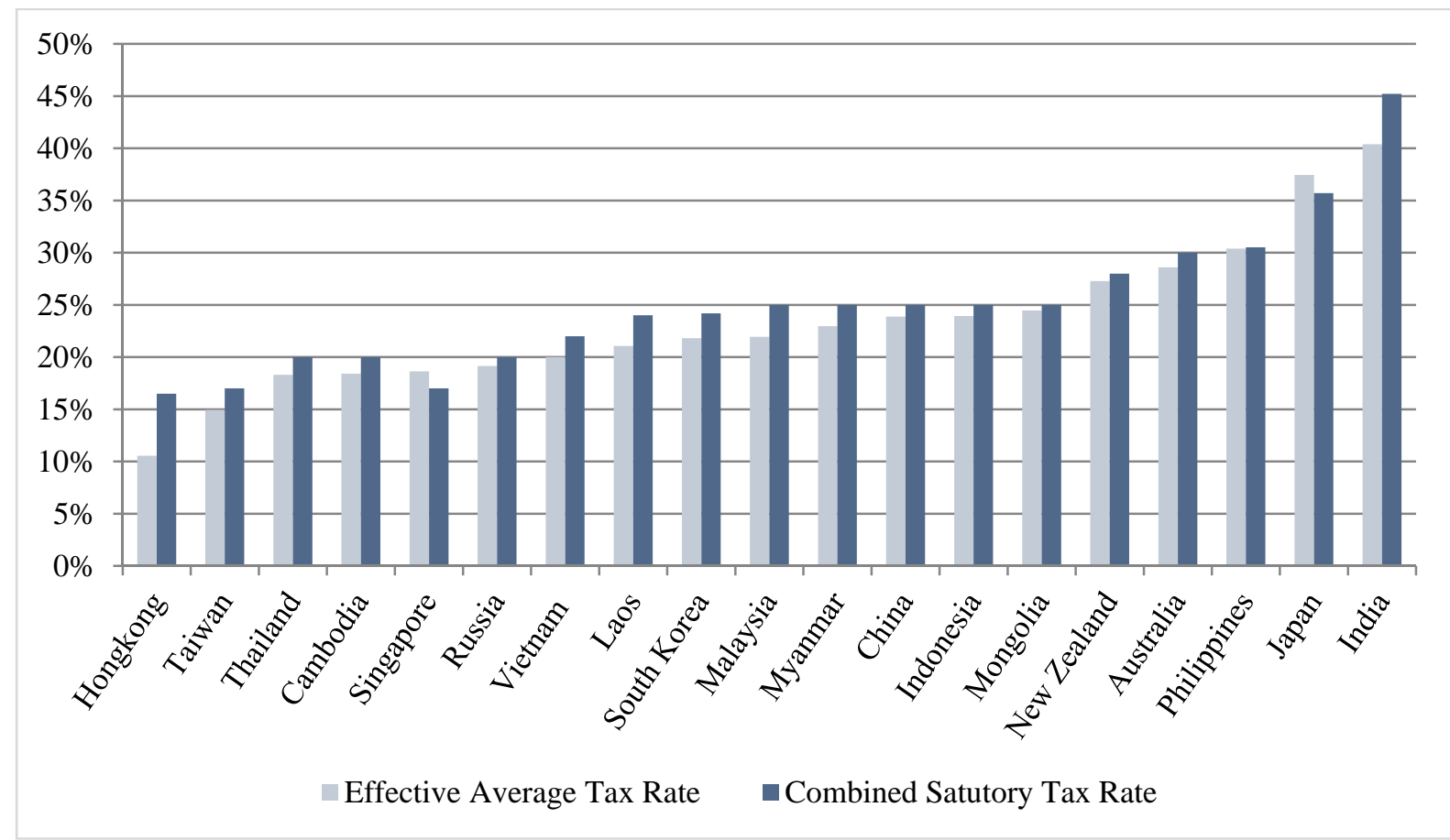

Source: Own calculations. For exact values see Table A5.

\subsection{Analysis of Effective Tax Burdens on Cross-Border Investments}

Asia-Pacific countries are top destinations for FDI. In its Regional Economic Outlook 2014 the IMF reports that countries in Emerging Asia attract nearly one quarter of worldwide FDI. ${ }^{18}$ In 2012 FDI into countries covered by this survey has been more than four times higher than in 2000 and even ten times higher than in $1993 .{ }^{19}$

In 2008 China ended its preferential tax treatment for foreign investment enterprises (FIEs). Against the background of this tax reform, An (2012) sets up a quasi-experiment providing empirical evidence on the impact of taxation on FDI for an Asian jurisdiction. It is shown that foreign investors, who no longer receive preferential tax treatment after the reform, respond by reducing their investment in China. ${ }^{20}$ Moreover, the study confirms that taxation impacts FDI in emerging economies in Asia We therefore address the effective tax burden of inbound investments into Asia-Pacific in the following section.

Several additional tax factors have to be considered for such an investment. Firstly, payments from the subsidiary to the parent company, like dividends and interests, are subject to withholding taxes in most Asia-Pacific territories. In some cases this additional tax burden can be reduced by tax treaties between the investment's host and home country. This is, for example, the case for an outbound investment from Germany to the Philippines where the original withholding tax rate on dividends is reduced from $15 \%$ to $10 \%$. An overview of withholding tax rates levied on dividends and interests is provided in Table A6 in the appendix. The rates presented are those for outbound investments from Germany, Singapore and the US, all of which will be discussed in the following. Secondly, dividend and interest

\footnotetext{
${ }^{18}$ See IMF (2014a) p. 21. According to the definition of the IMF, Emerging Asia covers all countries located in the Asia-Pacific region - excluding developed countries. See IMF (2014b).

${ }^{19}$ See UNCTAD (2014a) Database. Prior to 1993 no data for Russia are available.

${ }^{20}$ An (2012) p. 669.
} 
payments received by the parent company can be subject to corporate income tax in the investment's home country. To avoid double taxation these jurisdictions might either fully exempt dividends from taxation or credit taxes paid abroad when computing the tax liability. The latter method is also applied to avoid double taxation of interests. In the following we address the effects of both methods.

\section{a. German Outbound Investment}

The first cross-border scenario we consider in our analysis covers investments by a German parent company into any of the Asia-Pacific jurisdictions. Dividend payments received by the parent company are exempt from taxation in Germany. Meanwhile, the credit method is applied for interest payments. Additionally, 5\% of dividend payments between affiliates are regarded as business expenses and are thus subject to taxation. Germany further signed tax treaties with most of the jurisdictions considered by this paper. Exemptions are Cambodia, Laos and Myanmar.

Figure 2 compares the EATR for domestic investments and investments by a German parent company. In this setting an investment to Japan (43.6\%) still bears the highest effective tax burden, while the EATR for Hong Kong (12.1\%) remains the lowest. Considering the average of all countries, the average EATR for investments in the Asia-Pacific region increases from $23.4 \%$ to $29.2 \%$. From the perspective of a German investor, withholding taxes on dividends, have a significant impact, on the ranking of investment locations according to effective tax burdens, because they cannot be credited and thus become a definite tax burden. Territories that do not levy any withholding taxes on dividends, such as Vietnam, Malaysia and Myanmar, are relatively more attractive for an outbound investment from Germany than for a domestic one. For other jurisdictions, such as Cambodia and Taiwan, withholding taxes result in an increase of the EATR by more than 10 percentage points compared to the domestic case. For cross-border investments from Germany the EATR is higher than 35\% in five countries, namely the Philippines, New Zealand, Australia, India and Japan. 
Figure 2 - Comparison of effective average tax rates of domestic and German outbound investments in the Asia-Pacific region

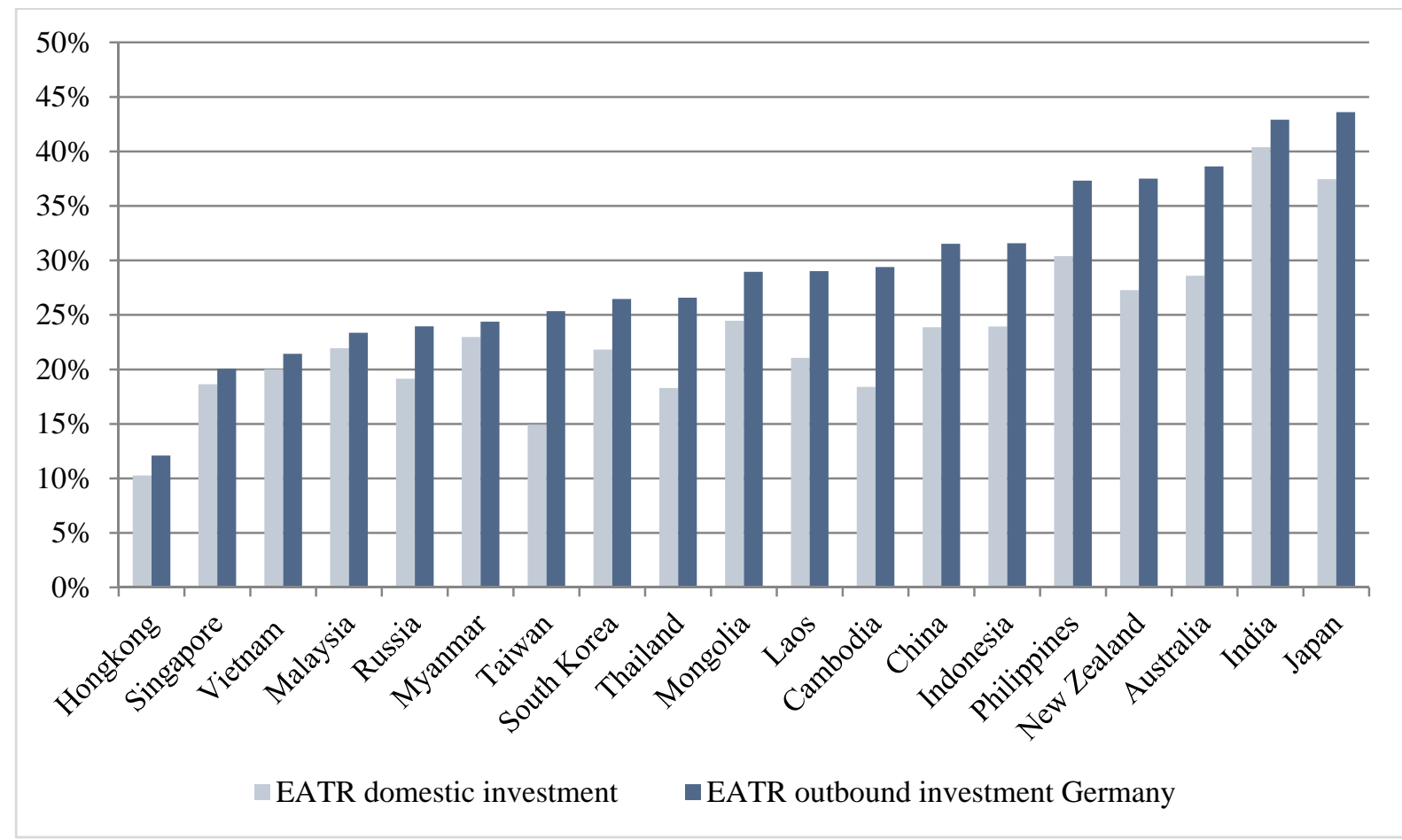

Source: Own calculations. For exact values see Table A5.

\section{b. Singaporean Outbound Investment}

To address the increasing importance of regional headquarters in Asia-Pacific, we further investigate the effective tax burden of outbound investments from Singapore. Singapore is not only one of the top host destinations for foreign investments (currently ranked number 8), but also belongs to the top 16 investing economies worldwide. ${ }^{21}$ As early as $2003^{22}$ the Singaporean government set up a Headquarter Programme to promote the creation of a headquarter hub attracting overhead activities from all kinds of industries and geographic origins. ${ }^{23}$ Companies participating in the programme are entitled to tax incentives, which will be further assessed in Section 4 of this paper.

Figure 3 presents the EATR on investments by a Singaporean parent company in other AsiaPacific jurisdictions. To avoid double taxation of dividends, Singapore fully exempts income from dividends. An investment in a subsidiary located in Hong Kong receives the most preferential tax treatment (EATR of 11.9\%). With regard to investments in Taiwan, we observe significant changes compared to the domestic setting. In a domestic setting the effective tax burden of Taiwanese investments is the second lowest (14.9\%). However, Taiwan and Singapore do not have any tax treaty in place. Withholding tax rates of $20 \%$ on dividend and interest payments ${ }^{24}$ to a Singaporean parent company thus result in an EATR that is as high as $32.6 \%$ for this particular cross-border scenario. Only investments in four other jurisdictions bear higher tax burdens.

\footnotetext{
${ }^{21}$ See UNCTAD (2014b) pp. xiv and xv.

${ }^{22}$ See Leow/Wong/Ke (2010).

${ }^{23}$ See Singapore Economic Development Board (2014).

${ }^{24} 20 \%$ is the highest rate levied by any of the Asia-Pacific jurisdictions.
} 
The average EATR for a Singaporean inbound investment in other Asia-Pacific countries is 29.2\% and thus the same as for a German parent company. Differences in the ranking between the Singaporean and the German scenario can be attributed to two major determinants. Firstly, both countries differ with respect to the treaty structure and withholding tax rates applicable in the host countries. In particular, investments in China, New Zealand or Japan are more favourable in terms of taxation from a Singaporean investor's perspective than from a German one. ${ }^{25}$ The respective EATRs in case of a German parent company are 31.5\%, $37.5 \%$ and $43.6 \%$ compared to $28.4 \%$, 31.7\% and $41.4 \%$ for investments from Singapore. For all three settings these differences result from lower withholding taxes on dividends. By contrast, the example of Myanmar shows that lower withholding tax rates on interest payments do not have a significant impact on the EATR. ${ }^{26}$

Figure 3 - EATRs of Singaporean outbound investments in the Asia-Pacific region

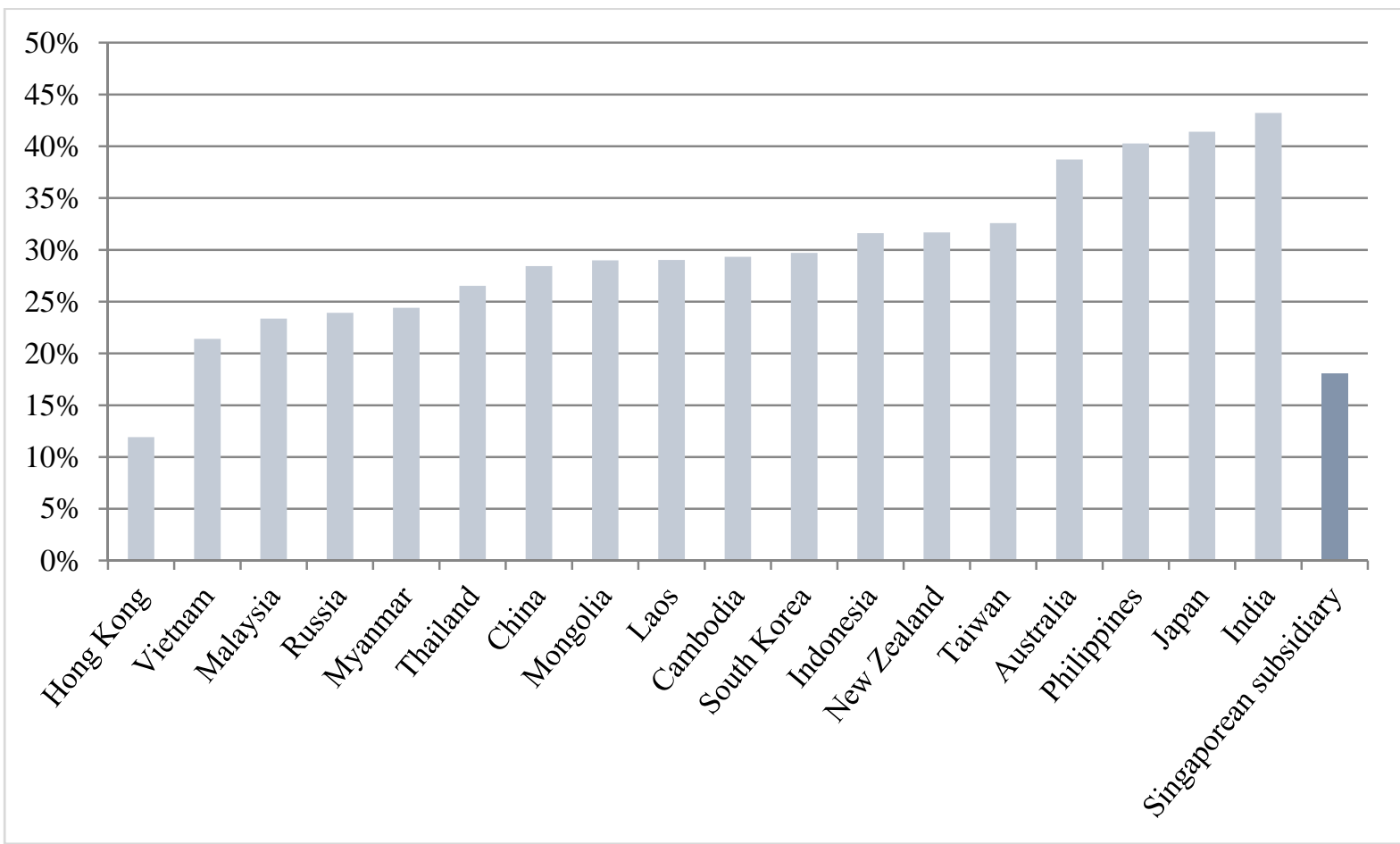

Source: Own calculations. For exact values see Table A5.

Secondly, the EATR is affected by the source of finance applied on the parent and the subsidiary level. Since interest payments are deductible for tax purposes in most cases, it is more favourable to finance an investment from a low-tax country to a high-tax country by granting a loan to the subsidiary. This method helps to shift profits in form of interest payments to the low-tax country. The example of an outbound investment to Malaysia illustrates this effect. Since the corporate income tax is $8 \%$ percentage points lower in Singapore than in Malaysia, interests deducted from the tax base in Malaysia are taxed at the lower Singaporean corporate income tax rate. Meanwhile interest payments received by a

\footnotetext{
${ }^{25}$ The Chinese and the German government already signed a new tax treaty in March 2014, which has yet to be ratified by the respective legislative bodies. If it enters into force, withholding taxes on dividends paid by a Chinese subsidiary will be reduced to 5\% (compared to 10\% nowadays). Federal Republic of Germany/People’s Republic of China (2014).

${ }^{26}$ The EATR for both scenarios differs by 0.02 percentage points, while withholding tax rates on interest payments differ by 5 percentage points.
} 
German parent company bear a higher tax burden than under Malaysian tax law. Equity financing thus results in a lower tax burden for the German investor. According to the assumptions made for the purpose of this paper, the majority of the investment is financed by equity, which leads to a slight advantage for the German investor (EATR of 23.36\% compared to $23.37 \%$ in Singapore). The comparison of Singapore and Germany clearly highlights the importance of international tax treaties ${ }^{27}$ and the way an investment is financed.

\section{c. American Outbound Investment}

In the US, dividend payments by affiliates are not exempt from taxation at home but instead taxes paid abroad can be credited against claims by the US tax authorities. As our results presented in Figure 4 show, the impact of the host country's corporate income tax rate on the overall tax burden is substantially limited by the underlying US credit regime. The EATR of a domestic investment in the US is currently at $36.5 \%$. The assumption that part of the investment is financed by retained earnings partially limits taxation by the home country. Most cross-border investments thus still face a lower tax burden than a domestic one. Only investments in countries that apply higher tax rates than the US, namely Japan, the Philippines and India, bear an excess overall effective tax burden. For the remaining jurisdictions the EATR ranges from 29.1\% for Hong Kong to 36.5\% for an investment in Mongolia.

Non-income taxes that are not creditable against the US tax liability gain in importance. Whereas Russia ranks among the five most favourable destinations in terms of taxation for investments from Germany and Singapore, the country, from a tax perspective, hardly makes it to the top ten list of an US investor. This outcome results from a $2 \%$ real estate tax imposed on investments in Russia.

In addition to non-income taxes and retained earnings, the effective tax burden is further influenced by the computation of the tax burden. Although the US corporate income tax rate is applied to compute the minimum tax burden on dividends received by a subsidiary located in Asia-Pacific, the host country's tax code determines the underlying tax base. An investment in Laos is effectively taxed at $30.1 \%$, while a tax of $30.7 \%$ is levied on a Vietnamese subsidiary owned by a US parent company. Looking at the national tax code of Laos and Vietnam, the Vietnamese tax on corporate income (currently at 22\%) is 2 percentage points lower than the one in Laos and both countries do not levy any non-income tax. However, Laotian tax depreciation patterns for intangibles and machinery allow for faster tax depreciation than Vietnamese regulations (2 and 5 years on a straight-line basis compared to 10 and 7 years) and thus contribute to the increased attractiveness of a subsidiary located in Laos.

\footnotetext{
${ }^{27}$ One might argue that multinationals often have the possibility to engage in so-called treaty shopping. Multinational conglomerates can exploit favourable tax treaties between specific countries by setting up complex corporate structures.
} 
Figure 4 - EATRs of US outbound investments in the Asia-Pacific region

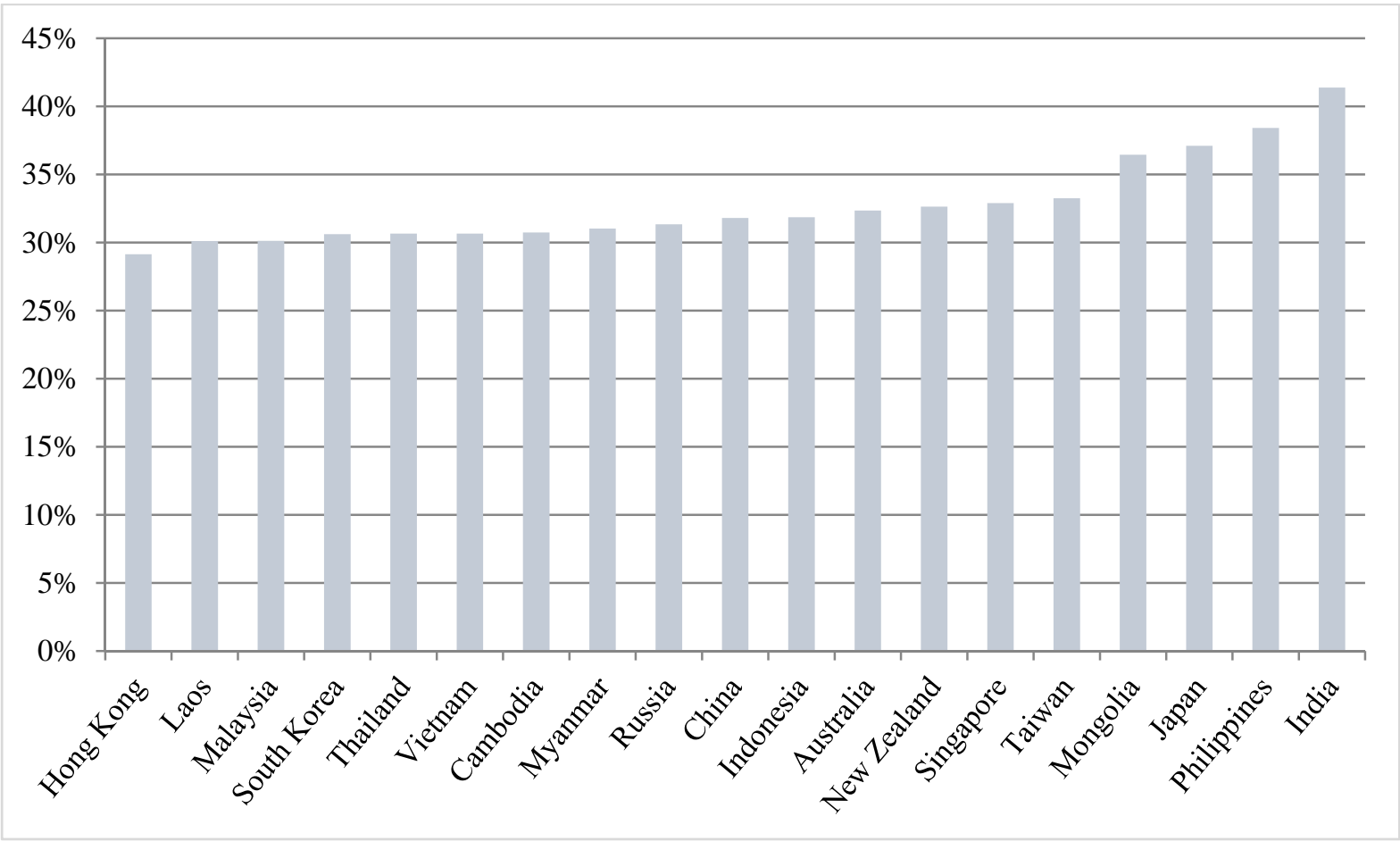

Source: Own calculations. For exact values see Table A5.

Our analysis of investments in an international setting shows that several additional factors have to be taken into account when evaluating tax burdens of FDI (with partial repatriation of income) in the Asia-Pacific region. No matter where the parent company is located, the EATR increases compared to a solely domestic scenario. From the perspective of an investor resident in a country that exempts foreign dividends, the level of withholding taxes as well as the choice of financing are the main drivers of the overall tax burden. Parent companies located in jurisdictions, which apply the credit method, on the contrary, cannot benefit from a more favourable tax treatment of corporate income at the subsidiary level. In case of a cross-border scenario, effective tax burdens of investments in countries where profits are taxed at lower rates are effectively grossed-up to the tax level paid at home. Withholding taxes only matter if the tax level in the investment's host country is higher than the one at home. ${ }^{28}$

\section{Impact of Corporate Tax Incentives on the Effective Tax Burden}

\subsection{Overview of Tax Incentives in the Asia-Pacific Region}

In order to promote the investment location of the respective territory, policy makers in all countries covered by this study rely on tax incentives. Tax incentives (sometimes also referred to as fiscal incentives) are defined as measures that provide preferential tax treatment for certain activities, assets, sectors and forms of financing over others and are exceptions to what

\footnotetext{
${ }^{28}$ See, for example, investment by a US parent company in a subsidiary located in the Philippines.
} 
is granted under the general tax regime. ${ }^{29}$ The most common types of tax incentives are socalled tax holidays, periods for which an investment is fully exempt from taxation, reduced tax rates, accelerated depreciation, tax credits and investment allowances. As a general rule, all types of fiscal incentives aim at lowering the tax burden ${ }^{30}$ of a specified investment. In the following this paper will focus on tax incentives for corporate investors, which intend to encourage economic activity, in particular capital accumulation in certain sectors or geographic areas.

Most countries use fiscal incentives to target specific sectors that are considered essential for the country's economy. New Zealand, for example, offers incentives for the extractive and mining industry while China focuses on software and integrated circuit industries. Figure 5 groups the main types of tax incentive according to the objectives for which they have been implemented. The most common reason for tax incentives is the stimulation of research and development (R\&D) activities and the promotion of development in certain regions of the investment's host country. Regions targeted by tax incentives are mostly remote or less developed areas. This type of incentive is also seen as a compensation to the investors for increased transportation and communication costs as well as extra costs to attract skilled labour. ${ }^{31}$ While incentives for R\&D activities are especially common in developed countries of the region, regional incentives are more widespread in developing and less-developed countries. ${ }^{32}$ For a detailed list of incentives offered by each country refer to Table A7, which is included in the appendix. Arguing that good infrastructure attracts new investment, ${ }^{33}$ most transition economies also encourage investors to engage in infrastructure development projects. A rather new phenomenon is incentives for investments in renewable energy, environmental protection projects and environmental-friendly equipment and machinery, ${ }^{34}$ which has become especially popular among advanced economies. Both types of incentives have been implemented by nearly half of the Asia-Pacific countries. Many fiscal incentives also address unemployment issues, while a growing number of incentives aim at improving the quality of the local labour force by providing special tax benefits for employee training. To mention some prominent examples, Japan grants a tax credit of $10 \%$ on the increased amount of salary payments if the wage level rises by $5 \%$ or more compared to a specified base year. In Malaysia, expenses for training activities for local employees of a manufacturing business, which has not yet started its core operations can be deducted twice. Although so far incentives for high technology industries are not among the most widespread incentives in the region, very often these incentives offer the most beneficial tax treatment for investors as we will show in the following.

\footnotetext{
${ }^{29}$ See Shah (1995) p. 2; UNCTAD (2000) p. 12; Klemm (2010) pp. 315 f. Definitions in these papers differ slightly depending on the focus of the respective work. For the purpose of this paper, a combination of these definitions that best fits the usage of the term "tax incentive" throughout the following pages is adopted.

${ }^{30}$ See Zee/Stotsky/Ley (2002) p. 1497.

${ }^{31}$ See UNCTAD (2000) p.15.

${ }^{32}$ For the purpose of this paper, countries are classified into "advanced economies" and "emerging and developing" countries according to the World Economic Outlook groups of the IMF. The group of the least developed countries is adopted from the United Nations Statistic Division.

${ }^{33}$ See Introduction and OECD (2007) p.77.

${ }^{34}$ These investment types are summarized as "environmental protection" in Figure 5.
} 
Figure 5 - Targets of tax incentives in the Asia-Pacific region

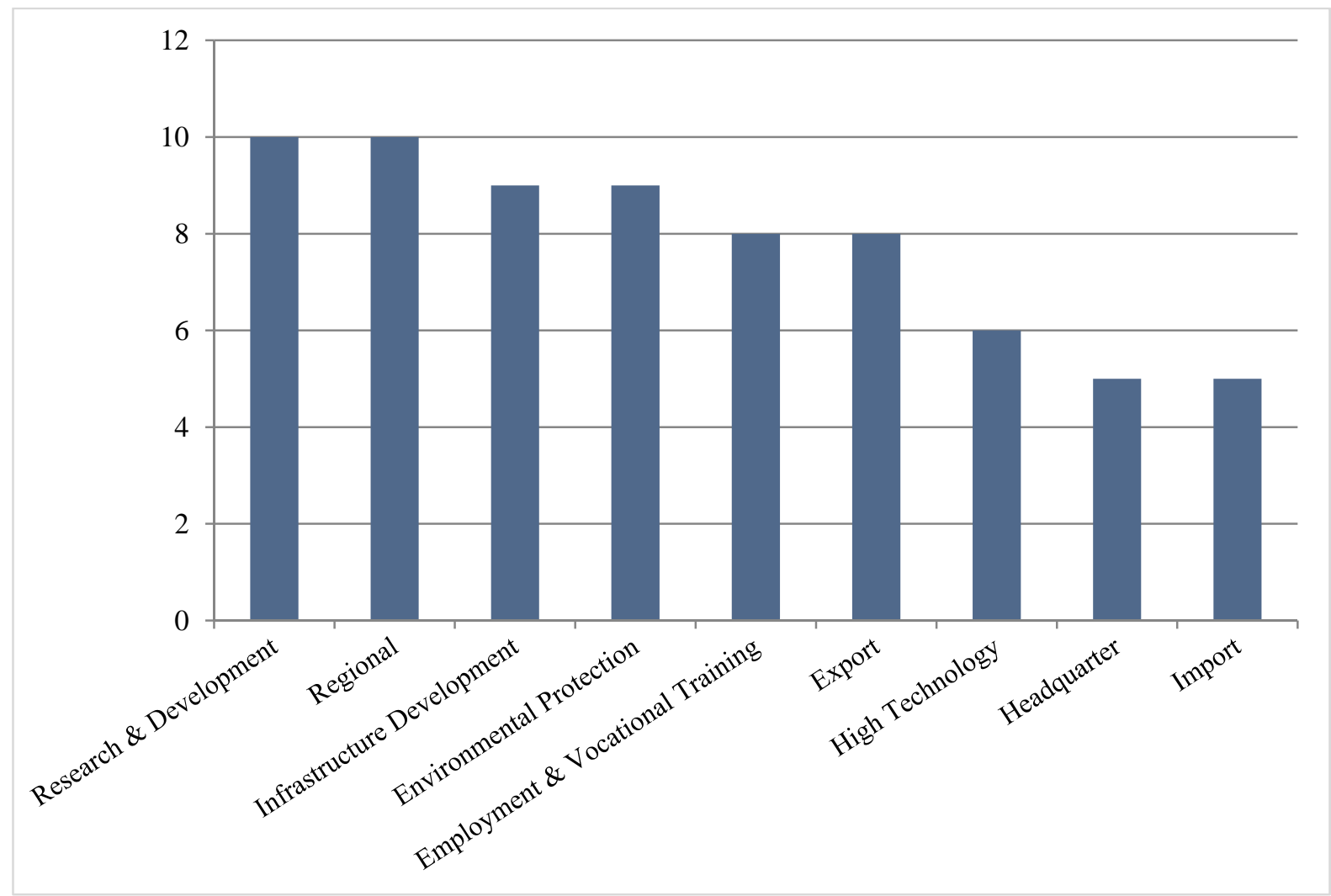

Source: Own survey based on IBFD Tax Research Platform.

This figure illustrates the total number of countries in Asia-Pacific that introduced the respective type of tax incentives.

\subsection{Impact of Tax Incentives on the EATR}

As a first step, we compute the EATRs for investments that qualifies for the most beneficial tax incentive in terms of tax reduction. Thereafter incentives for specific geographic regions and investments in the high technology sector will be analysed in greater detail.

We now include different types of fiscal incentives, namely accelerated depreciation, tax credits, tax holidays and reduced tax rates in the initial model. Accelerated depreciation speeds up depreciation of industrial buildings, machinery and intangibles. Timing effects resulting from the time value of money increase the present value of depreciation allowances and thus reduce the investment's tax base. ${ }^{35}$ Tax credits lower an investment's tax burden by being directly added to the present value of tax allowances. ${ }^{36}$ Tax holidays and reductions of the corporate income tax rate are captured by the present value of the respective tax rate. For profitable investments, ${ }^{37}$ fiscal incentives such as tax holidays, which directly impact the tax rate applied, have a larger effect on an investment's effective tax burden than measures reducing the investment's tax base. This outcome becomes plausible when looking at the model applied in our analysis. When computing the EATR we consider a profitable investment instead of a marginal investment. In this setting the statutory tax rate's impact is

\footnotetext{
${ }^{35}$ For a detailed explanation of the so-called tax base effect see Schreiber (2013) p. 30.

${ }^{36}$ See King/Fullerton (1984) p.19.

${ }^{37}$ Our analysis assumes a profitable investment compared to a marginal investment. See Table A1 - Underlying assumptions.
} 
more significant. Meanwhile, effects arising from the computation of the tax base are limited, as the present value of tax allowances is independent from the investment's profitability.

Some countries like Australia, Japan and Taiwan offer incentives for R\&D activities. However, since the focus of this paper is on investments by a manufacturing entity, such incentives will not be included in the analysis. ${ }^{38}$ Moreover, we further exclude certain incentives as those for exploration projects of the extractive industries in New Zealand. ${ }^{39}$ Table 1 summarizes the incentives modelled for the remaining 15 countries and briefly describes the conditions under which they are offered.

\footnotetext{
${ }^{38}$ For studies on the impact of tax regimes that promote R\&D activities see among others Ernst/Spengel (2011) and Evers/Miller/Spengel (forthcoming).

${ }^{39}$ For a detailed description of additional tax incentives offered by countries in the Asia-Pacific region see Endres/Fuest/Spengel et al. (2010).
} 
Table 1 - Overview of tax incentives available for manufacturing entities in Asia-Pacific

\begin{tabular}{|c|c|c|c|}
\hline Jurisdiction & Type of incentive & Target* & Conditions \\
\hline Cambodia & Tax holiday of 6 years & - & $\begin{array}{l}\text { Qualified investment projects involved in } \\
\text { the production and processing of goods. }\end{array}$ \\
\hline \multirow[t]{2}{*}{ China } & $\begin{array}{l}\text { Permanently reduced corporate } \\
\text { income tax rate of } 15 \% \text { and a } \\
\text { tax holiday of } 2 \text { years followed } \\
\text { by a } 50 \% \text { reduced tax rate for } 3 \\
\text { years }\end{array}$ & $\begin{array}{l}\text { Regional \& } \\
\text { high technology }\end{array}$ & $\begin{array}{l}\text { Foreign investment enterprises (FIEs) } \\
\text { investing in Western regions of the } \\
\text { country are all subject to the reduced tax } \\
\text { rate. If the investment is undertaken in the } \\
\text { Xinjiang Province, the investment is } \\
\text { further eligible to the tax holiday and the } \\
\text { temporary reduction. NHTEs can also } \\
\text { receive this additional incentive if located } \\
\text { in one of the Special Economic Zones } \\
\text { (SEZs). }\end{array}$ \\
\hline & $\begin{array}{l}\text { Permanently reduced corporate } \\
\text { income tax rate of } 15 \%\end{array}$ & High technology & $\begin{array}{l}\text { New and high technology enterprises } \\
\text { (NHTE) }\end{array}$ \\
\hline Hong Kong & $\begin{array}{l}\text { 100\% write-off for new capital } \\
\text { expenditure }\end{array}$ & $\begin{array}{l}\text { Environmental } \\
\text { protection }\end{array}$ & $\begin{array}{l}\text { High-value manufacturing businesses } \\
\text { investing in plant and machinery for } \\
\text { manufacturing, in computer hardware and } \\
\text { software or environmental protection } \\
\text { facilities. }\end{array}$ \\
\hline \multirow[t]{2}{*}{ India } & $\begin{array}{l}\text { Tax holiday of } 5 \text { years followed } \\
\text { by a } 50 \% \text { reduced tax rate for } \\
10 \text { years }\end{array}$ & - & $\begin{array}{l}\text { Newly established investments that } \\
\text { manufacture goods or offer services in } \\
\text { one of the SEZs. }\end{array}$ \\
\hline & Tax holiday of 10 years & Regional & $\begin{array}{l}\text { Manufacturing projects located in one of } \\
\text { the North Eastern states. }\end{array}$ \\
\hline \multirow[t]{2}{*}{ Indonesia } & Tax holiday of 10 years & - & $\begin{array}{l}\text { Companies that operate in one of the } 5 \\
\text { designated pioneer industries basic } \\
\text { metals, oil refining and petrochemicals, } \\
\text { renewable resources, industrial machinery } \\
\text { and telecommunication equipment. }\end{array}$ \\
\hline & $\begin{array}{l}\text { Accelerated depreciation at } \\
\text { double rates for buildings, other } \\
\text { tangible and intangible assets, } \\
50 \% \text { reduction of withholding } \\
\text { tax on dividends }\end{array}$ & Regional & $\begin{array}{l}\text { Businesses located in economic } \\
\text { development zones or hardship areas that } \\
\text { lack social and economic infrastructure. }\end{array}$ \\
\hline Laos & Tax holiday of 10 years & Regional & $\begin{array}{l}\text { Investments in zone } 1 \text {, which is described } \\
\text { as remote areas where no economic } \\
\text { infrastructure exists and activities } \\
\text { specified as level } 1 \text {. The Investment } \\
\text { Promotion Law of } 2009 \text { assigns most } \\
\text { manufacturing activities to level } 1 \text {. }\end{array}$ \\
\hline Malaysia & Tax holiday of 5 years & $\begin{array}{l}\text { Regional \& } \\
\text { high technology }\end{array}$ & $\begin{array}{l}\text { Entities with pioneer status, which engage } \\
\text { in promoted activities such as high } \\
\text { technology or are located in promoted } \\
\text { areas. }\end{array}$ \\
\hline Mongolia & Tax credit of $10 \%$ & - & $\begin{array}{l}\text { Entities starting new, expanding or } \\
\text { renovating existing production in certain } \\
\text { priority sectors. }\end{array}$ \\
\hline
\end{tabular}




\begin{tabular}{|c|c|c|c|}
\hline Myanmar & $\begin{array}{l}\text { Tax holiday of } 5 \text { years, followed } \\
\text { by a } 50 \% \text { reduced tax rate for } 5 \\
\text { years plus additional } 5 \text { years for } \\
\text { reinvested profits }\end{array}$ & $\begin{array}{l}\text { Regional \& } \\
\text { export }\end{array}$ & $\begin{array}{l}\text { Foreign investments carried out in a SEZ. } \\
\text { After the expiry of this incentive } \\
\text { additional tax reliefs for exporting } \\
\text { enterprises are possible. }\end{array}$ \\
\hline Philippines & Tax holiday of 6 years & Regional & $\begin{array}{l}\text { Newly established pioneer firms that, for } \\
\text { example, produce products that are not } \\
\text { yet manufactured in the Philippines or } \\
\text { enterprises located in less-developed } \\
\text { areas. }\end{array}$ \\
\hline Russia & $\begin{array}{l}\text { Depreciation at double rates } \\
\text { and exemption from property } \\
\text { tax for } 5 \text { years }\end{array}$ & Regional & Investments located in SEZs. \\
\hline Singapore & Tax holiday of 15 years & High technology & $\begin{array}{l}\text { Projects that are considered to have } \\
\text { favourable prospects for development and } \\
\text { are not yet undertaken at a sufficient scale } \\
\text { in Singapore. }\end{array}$ \\
\hline South Korea & $\begin{array}{l}\text { Tax holiday of } 5 \text { years followed } \\
\text { by a } 50 \% \text { reduced tax rate for } 2 \\
\text { years }\end{array}$ & High technology & $\begin{array}{l}\text { High technology enterprises located in } \\
\text { foreign investment zones. }\end{array}$ \\
\hline \multirow[t]{2}{*}{ Thailand } & $\begin{array}{l}\text { Tax holiday of } 8 \text { years followed } \\
\text { by a } 50 \% \text { reduced tax rate for } 5 \\
\text { years }\end{array}$ & Regional & $\begin{array}{l}\text { Investment in the predefined zone } 3 \text { (less } \\
\text { industrialized regions of the country) } \\
\text { receive a full exemption of } 8 \text { years and if } \\
\text { the project is also located in one of the } \\
\text { special promoted zones the additional } \\
\text { reduction is granted. }\end{array}$ \\
\hline & Tax holiday of 8 years & $\begin{array}{l}\text { High technology } \\
\text { \& environmental } \\
\text { protection }\end{array}$ & $\begin{array}{l}\text { Among others, activities that involve high } \\
\text { technology or eco-friendly material and } \\
\text { products. }\end{array}$ \\
\hline Vietnam & $\begin{array}{l}\text { 10\% corporate income tax for a } \\
\text { period of } 15 \text { years, which } \\
\text { include full exemption for } 4 \\
\text { years and a further reduction to } \\
5 \% \text { for } 9 \text { years. }\end{array}$ & $\begin{array}{l}\text { Regional \& } \\
\text { High technology }\end{array}$ & $\begin{array}{l}\text { Projects undertaken in areas with extreme } \\
\text { socio-economic difficulties, investments } \\
\text { located in economic or high technology } \\
\text { zones, investments in the high technology } \\
\text { sector and enterprises that manufacture } \\
\text { software products }\end{array}$ \\
\hline
\end{tabular}

Source: IBFD Tax Research Platform

* In this table targets of the respective incentive are mentioned, if they can be assigned to one of the categories introduced in Figure 5.

This table summarizes all tax incentives (except for headquarters) that are incorporated in our analysis on effective tax burdens in the Asia-Pacific region. In line with our assumptions (see Table A1) we only consider tax incentives for manufacturing entities. For each country the incentives that result in the lowest tax burden are written in italics.

In case of China and Malaysia more favourable incentives would be available. However, both incentives apply for rather special cases. In Malaysia the project has to be recognized as one of strategic and national importance and in China the incentive is granted for entities engaged in public basic infrastructure projects or environmental protection projects. For India incentives for firms operating in SEZs are not considered as regional incentives, as the objective of the zones is to provide a competitive environment for exporting entities rather than promoting economic development of these regions.

Figure 6 illustrates the impact the most favourable incentives for each of territory have on an investment's effective tax burden. Except for Hong Kong and Russia, which offer accelerated depreciation for certain assets, in all other jurisdictions incentives offered as tax holidays and 
reduced tax rates provide the largest benefits for investors. In Singapore, Vietnam, Laos, Indonesia and China the EATR is lowered by half or more of the original tax burden. In this setting Hong Kong no longer offers the most attractive tax schedule. A tax holiday of 15 years reduces the EATR for investments in Singaporean pioneer industries to 7\%. Tax incentives available in Vietnam and Thailand also result in EATRs below the 10\% threshold. Meanwhile, Indonesia and China, two territories where the EATR for a standard investment is above average, become even more attractive than low-tax jurisdictions such as Cambodia and Russia. The highest possible EATR of an investment eligible for a preferential tax treatment is $22.6 \%$ and available for investments located in special economic zones in India.

Excluding the territories for which no incentives have been modelled, ${ }^{40}$ the EATR is on average reduced by 8.6 percentage points for investments in the Asia-Pacific region. However, this result would change if one considers a cross-border investment of an investor, whose home country applies the credit method as the US do. Such a tax regime causes the investor's gains from tax incentives to nearly vanish completely. In case of reduced tax rates or full exemption, the investment is still taxed at the higher US tax rate. The tax incentive thus simply shifts tax revenue from the host country to the home country.

In this context it is important to pay attention to the conditions an investment has to match in order to be eligible for the incentives mentioned above. If incentives of different targets are considered simultaneously, comparing investments with and without incentives in a specified country will lead to more robust conclusions than comparing jurisdictions among each other.

Figure 6 - Impact of the most beneficial tax incentives offered by each jurisdiction on the effective average tax burden

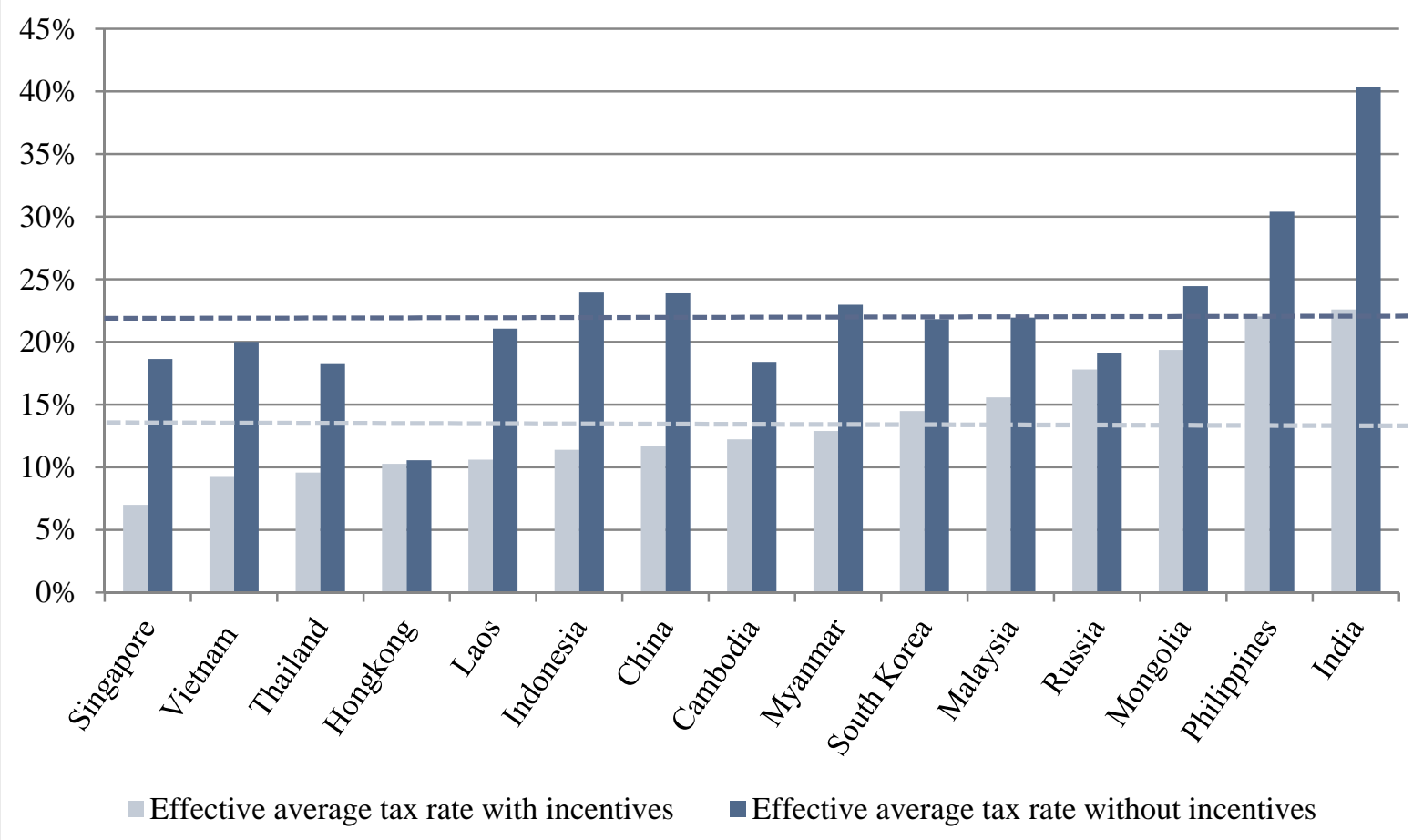

Source: Own calculations. For exact values see Table A8.In this diagram we only consider tax incentives resulting in the lowest effective average tax burden for a domestic investment. The dashed lines indicate the respective average EATR for investments with and without incentives. In this diagram the average of countries for which incentives have been modelled is used.

\footnotetext{
${ }^{40}$ These jurisdictions are Australia, Japan, New Zealand and Taiwan.
} 


\subsection{Focus on Regional and High Technology Tax Incentives}

So far our analysis has been limited to the most generous tax incentives in the Asia-Pacific region, illustrating important effects of such regulations. However, it is essential to bear in mind that not every investment project fulfils the requirements for these incentives. We showed that besides promoting R\&D activities, stimulating investment in selected geographic areas is the most common objective for policy makers to implement tax incentives. In half of the countries, incentives promoting development in specific regions result in the lowest effective tax burden. These countries are Vietnam, Thailand, Laos, China, Myanmar, Russia and the Philippines. Considering the impact of regional incentives on an investment's EATR, they reduce the tax burden by 5.7 percentage points on average. However, the majority of these incentives is only granted for investments in geographic areas that lack sufficient infrastructure and thus might require additional expenditures. Whether or not favourable taxation fully compensates the investor for such extra expenses remains uncertain. Several studies dealing with the merits of tax incentives in stimulating investment point out that the option of simply addressing such structural deficiencies by implementing tax incentives is only second best. ${ }^{41}$ They all conclude that if certain preconditions are not met, tax incentives will not be successful in attracting new investment. Governments should thus simultaneously try to reduce costs for such investments by investing in public infrastructure, education of the labour force and similar areas. ${ }^{42}$

Besides incentives targeted at the development of certain parts of a country, incentives implemented to increase investment in the high technology sector offer very favourable conditions for investors. In Singapore, Malaysia, South Korea and Vietnam such an investment is eligible for the most beneficial incentive. In China high technology enterprises have to be located in one of the SEZs to receive the most preferential tax treatment. However, independent of their location, these investments are already subject to a permanently reduced corporate income tax rate of $15 \%$ compared to the standard rate of $25 \%$. In Malaysia and Vietnam the tax treatment for investments in promoted regions and projects involving high technology is identical. Figure 7 compares the effective tax burden of investments eligible for regional and high technology incentives to investments that receive the most preferential tax treatment (independent of their preconditions) and to a standard domestic investment (see section 3). If the precondition of an investment that bears the lowest tax burden is related to its geographic location and/or the high technology sector, the EATR is again displayed in the respective column for regional and high technology incentives. Finally, it can be concluded that tax incentives, which have the highest impact on the tax burden of an investment in AsiaPacific, either try to promote regional development or investments in the high technology sector. The only exceptions to this conclusion are the two countries Cambodia and Mongolia, where the most favourable incentives are targeted at other industries.

\footnotetext{
${ }^{41}$ See UNCTAD (2000) p. 15, Zee/Stotsky/Ley (2002) p. 1499 and Klemm (2010) p. 334.

${ }^{42}$ See UNCTAD (2000) and Zee/Stotsky/Ley (2002).
} 
Figure 7 - Effective average tax burdens of investments targeted by high technology and regional incentives

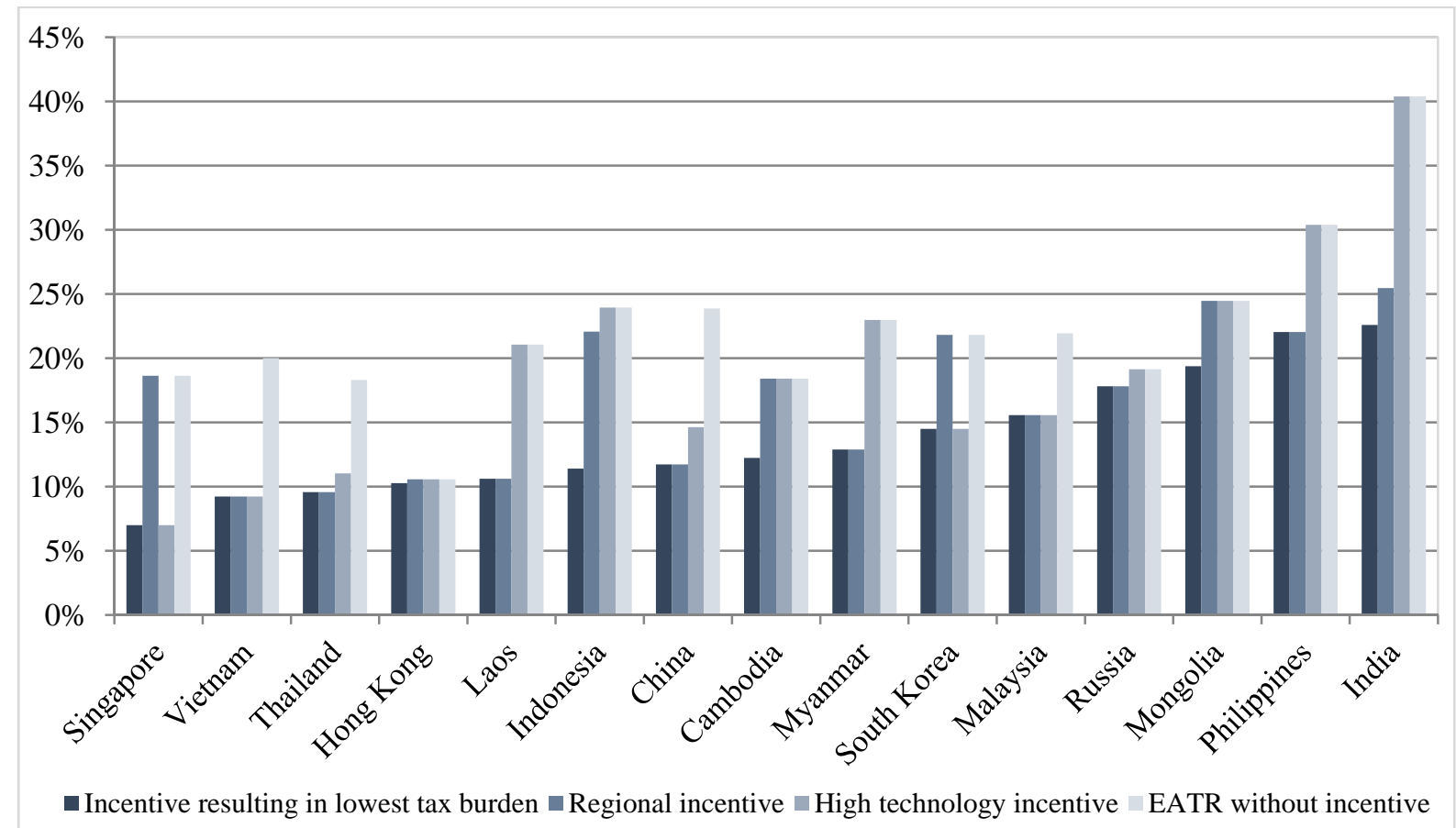

Source: Own calculations. For exact values see Table A8.

The figure above compares the impact of tax incentives that result in the lowest tax burden to tax incentives for investments in the high technology sector, in specific geographic regions and to a standard investment that does not qualify for any incentive. If no regional or high technology incentive is available for the respective jurisdiction, the EATR for a standard investment is depicted instead.

\subsection{Tax Incentives Promoting the Establishment of Headquarters}

As mentioned above, Singapore's incentive regime also offers special taxation rules implemented to attract regional and international headquarters (RHQs and IHQs). ${ }^{43}$ However, competition from other Asia-Pacific jurisdictions such as Hong Kong, China, Malaysia and Thailand is fierce, ${ }^{44}$ since having headquarters located in their country is often regarded as desirable by policy makers. Clausing (2010) states spill-over effects from R\&D and entrepreneurial activities and higher wage levels as possible benefits from headquarter activities. Moreover, Dischinger, Knoll and Riedel (2014) show that multinational headquarters are more profitable than their subsidiaries using panel data of European multinationals. Four countries in South East Asia and Australia thus provide special incentives to stimulate the establishment of RHQs and IHQs. ${ }^{45}$

\footnotetext{
${ }^{43}$ Whether an investment is considered a regional or an international headquarter depends on the level of commitment by the investor which has to differ substantially from the minimum requirements for a regional headquarter.

${ }^{44}$ See Leow/Wong/Ke (2010) p. 147.

${ }^{45}$ Australia, for example, defines regional headquarters as corporations which provide support to their associated companies located in other countries in the same region and act as intermediaries between associated companies and the non-resident parent company. In Singapore eligible corporations have to fulfil additional requirements such as a certain level of skilled workers, paid-up capital, activities etc. For a general discussion on the definition of headquarters for tax purposes see Clausing (2010) pp. 742-744.
} 
If located in Singapore, RHQs are awarded a reduced concessionary tax rate of $15 \%$ for 3 years, while IHQs can get a tax holiday for a maximum period of 20 years on incremental income. ${ }^{46}$ These incentives have a significant impact on the tax burden on incremental income directly generated by the respective headquarter. ${ }^{47}$ The incentive's impact on cross-border investments, however, is limited, as Singapore applies the exemption method for taxation of foreign dividends. Figure 8 compares the standard case presented in section 3.2 to an investment covered by Singapore's RHQ and IHQ awards. For Taiwan, Thailand, India, the Philippines and Cambodia the reduced corporate income tax rate granted by the IHQ award even has a negative effect on outbound investments to these countries. All of these jurisdictions levy particularly high withholding taxes on interest payments. If the home country's tax burden (in this case Singapore) drops below the withholding tax rate for interest payments, these withholding tax rates are final and the incentive loses its attractiveness. The tax burden on interest payments by the foreign subsidiary cannot be further reduced. Meanwhile, a lower corporate income tax rate impairs the parent company's tax shield. The fact that these two effects occur simultaneously leads to increased EATRs on Singaporean outbound investments to these countries.

Figure 8 - Comparison of effective average tax rates on outbound investments by a Singaporean headquarter

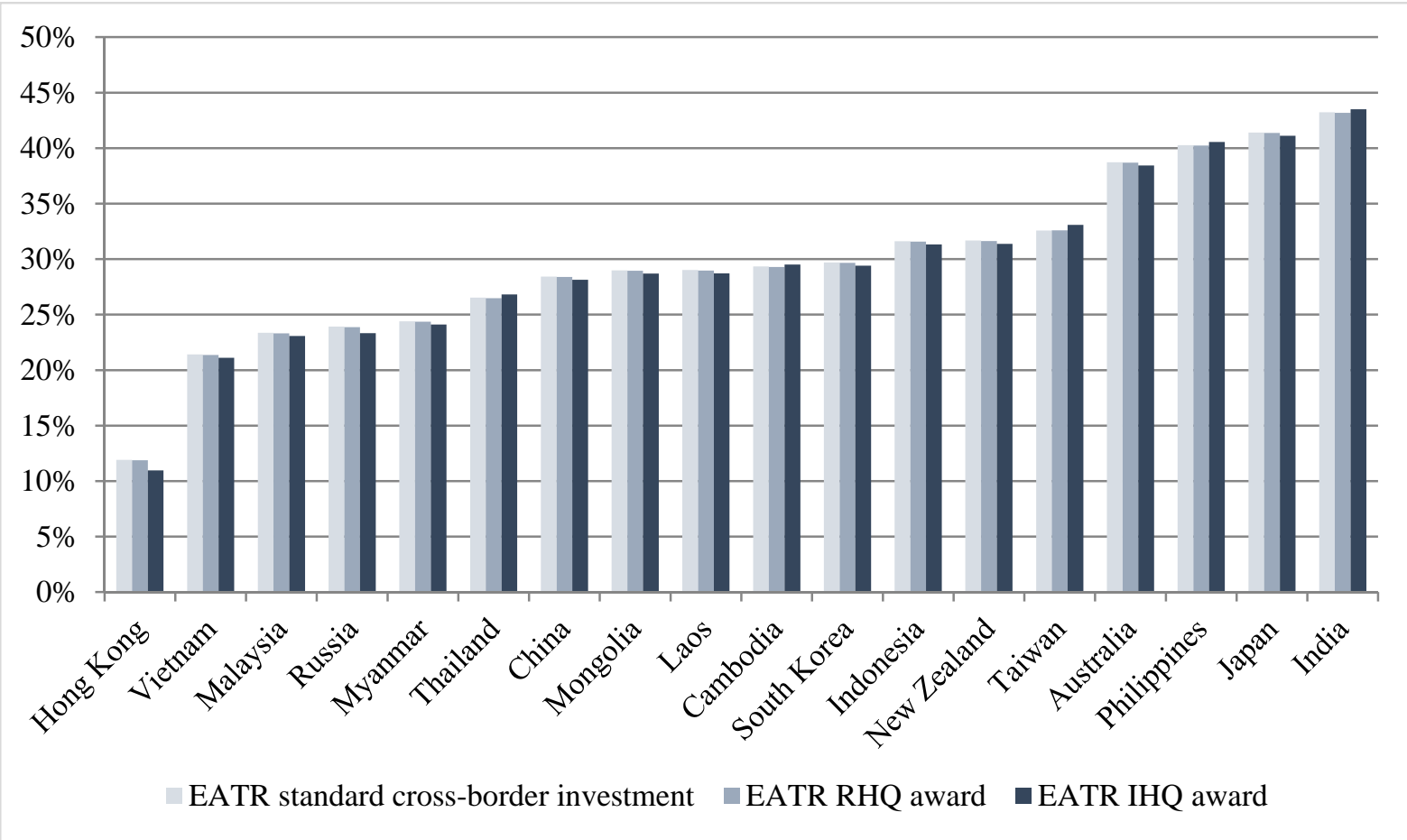

Source: Own calculations. For exact values see Table A9.

The figure displays standard investments by a Singaporean parent company, which have been introduced in section 3. These investments are now compared to two scenarios where the parent company is eligible for the RHQ award and IHQ award respectively and thus faces a lower corporate income tax rate in Singapore.

\footnotetext{
${ }^{46}$ The final incentive package awarded to international headquarters is subject to negotiations with the Economic Development Board (EDB). See Leow/Wong/Ke (2010) p.145.

${ }^{47}$ The model applied in our analysis is limited to dividends and interest payments between affiliates. Therefore the exact impact of headquarter incentives on the tax burden on management fees, royalties and other payments cannot be assessed by this model. Those payments, however, add up to income directly generated by headquarter activities. For a detailed analysis measuring the effective tax burden of different headquarter services (e.g. holding, financing and R\&D functions) see Bellingwout/Evers/Heckemeyer/Spengel (2012).
} 


\section{Conclusion}

The Asia-Pacific region has experienced dramatic economic transformations in the past decades. This development process has not come to a halt yet. Private investments are major drivers behind these economic dynamics, while taxation is one factor that influences location decisions of such investments. This paper takes a closer look at different tax policies implemented by 19 jurisdictions in Asia-Pacific and assesses the impact these policies have on the effective tax burden of investments. As a first step we compare national regulations on depreciation and amortization of assets used by manufacturing entities, describe valuation methods and tax rates on profits and property for each country. Based on these parameters, we apply a widely accepted approach introduced by Devereux and Griffith (1999 and 2003) to compute effective average tax burdens on investments in the Asia-Pacific region. Our analysis reveals the average EATR on domestic investments in all countries to be $23.4 \%$, while exact values range from $10.6 \%$ in Hong Kong to $40.4 \%$ in India. The taxation of cross-border investments further depends on the way foreign income is taxed in the investor's residence country. Whereas investors from Singapore and Germany benefit from the exemption of dividend income, if tax payments to authorities in the investment's host country are lower than at home, the credit method applied by the US government causes advantages resulting from lower tax rates in Asia-Pacific to almost vanish completely. FDI in any of the AsiaPacific jurisdictions by companies from Singapore or Germany is on average taxed at $29.2 \%$ and at $32.8 \%$ if undertaken by a US parent company. The comparison of investments by a Singaporean and a German investor illustrate the importance of withholding taxes on dividends and interest payments as well as of international tax treaties. A Singaporean parent company investing in a Taiwanese subsidiary faces an EATR of 32.6\%, whereas the EATR is at $25.3 \%$ for its German counterpart. Hereby the German investor benefits from withholding taxes that have been lowered by $50 \%$ by an agreement between the Taiwanese and German government. In order to attract additional investment to certain geographic areas, promoted industries or to reallocate resources to activities with spillover effects, policy makers in the Asia-Pacific region rely on tax incentives. Considering fiscal incentives that result in the lowest possible tax burden, such regulations can reduce the EATR by more than $50 \%$. Incentives promoting the high technology sector or regions with socio-economic difficulties offer the most preferential tax treatment for investments in the Asia-Pacific region. Moreover, regulations targeted at the development of predefined geographic areas are the most widespread type of tax incentives. Promising spill-over effects from headquarter activities motivate countries to introduce regulations that aim at attracting such investments. Our analysis for Singapore shows that cross-border tax regulations limit the impact these incentives have on FDI. The tax reducing effect is likely to be more significant if service activities and payments such as management fees are considered. Such an analysis, however, is beyond the scope of this paper. 


\section{References}

An Z. (2012), Taxation and foreign direct investment (FDI): empirical evidence from a quasiexperiment in China, International Tax and Public Finance 19, pp. 660-676

ASEAN Secretariat/World Bank (2013), ASEAN integration monitoring report, Washington D.C.

Bellingwout, J./Evers, L./Heckemeyer, J./Spengel, C. (2012), Corporate taxation of headquarter services in Europe, VU University of Amsterdam, Amsterdam and Mannheim

Clausing, K. (2009), Should tax policy target multinational firm headquarters? National Tax Journal 63, pp. 741-764

De Mooij, R./Ederveen, S. (2003), Taxation and Foreign Direct Investment: A Synthesis of Empirical Research, International Tax and Public Finance 10, pp. 673-693

Deng, S. (2011), Key Targets of China's 12th Five-Year Plan, http://news.xinhuanet.com/english2010/china/2011-03/05/c_13762230.htm, 18.12.2014

Devereux, M.P./Griffith, R. (2003), Evaluating tax policy for location decisions, International Tax and Public Finance 10, pp. 107-126

Devereux, M.P./Griffith, R. (1999), The taxation of discrete investment choices, The Institute for Fiscal Studies Working Paper Series W98/16 (Revision 2), London

Dischinger, M./Knoll, B./Riedel, N. (2014), There's No Place Like Home: The Profitability Gap between Headquarters and their Foreign Subsidiaries, Journal of Economics \& Management Strategy 23, pp. 369-395

Endres, D./Fuest, C./Spengel, C. in collaboration with Bartholomeß, A./Elschner, C./ Finke, K./Li, W./Lohse, T./Voget, J. (2010), Company Taxation in the Asia-Pacific Region, India, and Russia, $1^{\text {st }}$ Edition, Heidelberg

Ernst, C./Spengel, C. (2011), Taxation, R\&D Tax Incentives and Patent Application in Europe, ZEW Discussion Paper, No. 11-024, Mannheim

European Commission (2013), Effective tax levels using the Devereux/Griffith methodology, Final report 2012, Brussels

European Commission (2002), Company Taxation in the Internal Market, Commission Staff Working Paper, COM (2001) 582 final, Luxembourg

Evers, L./Miller, H./Spengel, C. (forthcoming), Intellectual Property Box Regimes: Effective Tax Rates and Tax Policy Considerations, International Tax and Public Finance, DOI 10.1007/s10797-014-9328-x

Federal Republic of Germany/People's Republic of China (2014), Abkommen zwischen der Bundesrepublik Deutschland und der Volksrepublik China zur Vermeidung der Doppelbesteuerung und zur Verhinderung der Steuerverkürzung auf dem Gebiet der Steuern vom Einkommen und vom Vermögen, March 2014, Berlin 
Feld, L.P./Heckemeyer, J.H. (2011), FDI and Taxation: A Meta-Study, Journal of Economic Surveys 25, pp. 232-272

IBFD (2014), Tax Research Platform, Online

IMF (2014a), Regional Economic Outlook: Asia and Pacific, World Economic and Financial Surveys, 0258-7440, April 2014, Washington D.C.

IMF (2014b), Country Composition of World Economic Outlook Groups, https://www.imf.org/external/pubs/ft/weo/2014/01/weodata/groups.htm, 01.06.2014

IMF (2012), Regional Economic Outlook: Asia and Pacific, World Economic and Financial Surveys, 0258-7440, April 2012, Washington D.C.

Jorgensen, D.W. (1963), Capital theory and investment behaviour, American Economic Review 53, pp. 247-259

King, M.A./Fullerton, D. (1984), The Taxation of Income from Capital: A Comparative Study of the United States, the United Kingdom, Sweden, and Germany, $1^{\text {st }}$ Edition, Chicago

Klemm, A. (2010), Causes, benefits, and risks of business tax incentives, International Tax and Public Finance 17, pp. 315-336

Leow, E./Wong, J.H.M./Ke, Z. (2010) Manufacturing and Trading Incentives - Where do we now stand in Asia, Singapore, Asia-Pacific Tax Bulletin pp. 144-147

OECD (2007), Tax Effects on Foreign Direct Investment: Recent Evidence and Policy Analysis, OECD Tax Policy Studies, No. 17, Paris

Shah, A. (1995), Overview, in: Shah, A. (Eds.), Fiscal Incentives for Investment and Innovation, New York, pp. 1-30

Singapore Economic Development Board (2014), Incentives for businesses http://www.edb.gov.sg/content/edb/en/why-singapore/ready-to-invest/incentives-forbusinesses.html, 18.12.2014

Schreiber, U. (2013), International Company Taxation: An Introduction to the Legal and Economic Principles, $1^{\text {st }}$ Edition, Heidelberg

Schreiber, U./Spengel, C./Lammersen, L. (2002), Measuring the Impact of Taxation on Investment and Financing Decisions, Schmalenbach Business Review 54, pp. 2-23

UNCTAD (2014a), UNCTADstat, http://unctadstat.unctad.org/ReportFolders/reportFolders.aspx, 18.12.2014

UNCTAD (2014b), World Investment Report 2014: Investing in the SDGs: An Action Plan, New York

UNCTAD (2013), World Investment Report 2013: Global Value Chains: Investment and Trade for Development, New York

UNCTAD (2000), Tax Incentives and Foreign Direct Investment: A Global Survey, ASIT Advisory Studies, No. 16, Geneva

World Bank (2014) World Bank Open Data, http://data.worldbank.org/indicator, 18.12.2014 
Zee, H.H./Stotsky, J.G./Ley, E. (2002), Tax Incentives for Business Investment: A Primer for Policy Makers in Developing Countries, World Development 30, pp. 1497-1516 


\section{Appendix}

Table A1 - Underlying assumptions

\begin{tabular}{|c|c|}
\hline Assumption on... & Value \\
\hline Legal form & Corporation \\
\hline Assets (weight) for manufacturing projects & $\begin{array}{l}\text { Industrial building (20\%), } \\
\text { intangible asset (20\%), machinery (20\%), } \\
\text { financial asset (20\%), inventory (20\%) }\end{array}$ \\
\hline Sources of finance (weight) & $\begin{array}{l}\text { Retained earnings (55\%), new equity (10\%), } \\
\text { debt (35\%) }\end{array}$ \\
\hline True economic depreciation & $\begin{array}{l}\text { Declining balance method; } \\
\text { industrial buildings } 3.1 \% \text {, intangibles } \\
15.35 \% \text {, machinery } 17.5 \%\end{array}$ \\
\hline Real interest rate & $5 \%$ \\
\hline Pre-tax real rate of return & $20 \%$ \\
\hline Inflation rate & $2 \%$ \\
\hline
\end{tabular}

Source: Endres/Fuest/Spengel et al. (2010) p. 17 and European Commission (2013).

Table A2 - Corporate income tax rates and other profit taxes

\begin{tabular}{lllll}
\hline Jurisdiction & $\begin{array}{l}\text { Nominal corporate } \\
\text { income tax }\end{array}$ & $\begin{array}{l}\text { Nominal } \\
\text { Surcharge }\end{array}$ & $\begin{array}{l}\text { Nominal } \\
\text { local profit tax }\end{array}$ & $\begin{array}{l}\text { Combined } \\
\text { statutory tax rate }\end{array}$ \\
\hline Australia & $30.0 \%$ & - & - & $30.0 \%$ \\
Cambodia & $20.0 \%$ & - & - & $20.0 \%$ \\
China & $25.0 \%$ & - & - & $25.0 \%$ \\
Hong Kong & $16.5 \%$ & - & - & $16.5 \%$ \\
India & $30.0 \% / 40.5 \%$ & $13.3 \%$ & - & $34.0 \% / 45.2 \%$ \\
Indonesia & $25.0 \%$ & - & - & $25.0 \%$ \\
Japan & $25.5 \% *$ & $20.7 \%$ & $7.7 \%$ & $35.7 \%$ \\
Laos & $24.0 \%$ & - & - & $24.0 \%$ \\
Malaysia & $25.0 \%$ & - & - & $25.0 \%$ \\
Mongolia & $25.0 \%$ & - & - & $25.0 \%$ \\
Myanmar & $25.0 \%$ & - & - & $25.0 \%$ \\
New Zealand & $28.0 \%$ & - & - & $28.0 \%$ \\
Philippines & $30.0 \%$ & - & $0.8 \%$ & $30.5 \%$ \\
Russia & $20.0 \%$ & - & - & $20.0 \%$ \\
Singapore & $17.0 \%$ & - & - & $17.0 \%$ \\
South Korea & $22.0 \%$ & $10.0 \%$ & $-24.2 \%$ \\
Taiwan & $17.0 \%$ & $10.0 \%$ & & $25.3 \% / 17.0 \%$ \\
& & & &
\end{tabular}




\begin{tabular}{lllll} 
Thailand & $20.0 \%$ & - & - & $20.0 \%$ \\
Vietnam & $22.0 \%$ & - & - & $22.0 \%$ \\
Germany & $15.0 \%$ & $5.5 \%$ & $15.1 \%^{* *}$ & $31.0 \%$ \\
United States & $35.0 \%$ & - & $8.8 \%$ & $37.9 \%^{* * *}$ \\
\hline
\end{tabular}

Source: IBFD Tax Research Platform.

* Until March 2015, corporations in Japan are subject to a 10\% surcharge on the corporate tax liability for reconstruction funding after the earthquake in 2011. This surcharge has not been included.

** The local profit tax in Germany comprises a basic rate of 3.5\% which is then multiplied by local multiplier set by each municipality. We assume a multiplier of 432, which represents the average rate of 2009 for municipalities with more than 50,000 inhabitants. This assumption follows European Commission (2013).

*** For the purpose of this paper, the corporate income tax rate levied in California is considered. In addition to the state tax on corporate income, the combined statutory tax rate includes a $9 \%$ deduction on federal tax available for domestic production activities.

Table A3 - Real estate and property tax rates

\begin{tabular}{|c|c|c|c|c|c|}
\hline \multirow{2}{*}{ Jurisdiction } & \multicolumn{2}{|c|}{ Real estate tax } & \multicolumn{3}{|c|}{ Property tax } \\
\hline & Nominal & Real & Nominal & Real & Assets covered \\
\hline Australia & - & - & - & - & - \\
\hline Cambodia & $0.10 \%$ & $0.08 \%$ & - & - & - \\
\hline China & $0.96 \%$ & $0.72 \%$ & - & - & - \\
\hline Hong Kong & - & - & - & - & - \\
\hline India & $2.48 \%$ & $1.64 \%$ & - & - & - \\
\hline Indonesia & $0.20 \%$ & $0.15 \%$ & - & - & - \\
\hline Japan & $0.30 \%$ & $0.19 \%$ & $1.40 \%$ & $0.90 \%$ & All assets \\
\hline Laos & - & - & - & - & - \\
\hline Malaysia & - & - & - & - & - \\
\hline Mongolia & - & - & $0.45 \%$ & $0.45 \%$ & Buildings and machinery \\
\hline Myanmar & - & - & - & - & - \\
\hline New Zealand & - & - & - & - & - \\
\hline Philippines & - & - & $2.40 \%$ & $1.68 \%$ & Buildings and machinery \\
\hline Russia & $2.00 \%$ & $1.60 \%$ & - & - & - \\
\hline Singapore & $0.50 \%$ & $0.42 \%$ & - & - & - \\
\hline South Korea & $0.23 \%$ & $0.17 \%$ & - & - & - \\
\hline Taiwan & $1.50 \%$ & $1.12 \%$ & - & - & - \\
\hline Thailand & $1.00 \%$ & $0.80 \%$ & - & - & - \\
\hline Vietnam & - & - & - & - & - \\
\hline Germany & 0.41 & $0.28 \%$ & - & - & - \\
\hline USA & - & - & $1.00 \%$ & $0.62 \%$ & Buildings and machinery \\
\hline
\end{tabular}

Platform. 
Table A4 - Depreciation and amortization of assets and inventory valuation

\begin{tabular}{|c|c|c|c|c|c|c|c|c|c|c|}
\hline \multirow[b]{2}{*}{ Jurisdiction } & \multicolumn{3}{|c|}{ Industrial Buildings } & \multicolumn{3}{|l|}{ Intangibles } & \multicolumn{3}{|c|}{ Machinery } & \multirow[t]{2}{*}{ Inventory valuation } \\
\hline & $\begin{array}{l}\text { Kind of } \\
\text { allowance }\end{array}$ & $\begin{array}{l}\text { Allowance } \\
\text { rate (\%) }\end{array}$ & $\begin{array}{l}\begin{array}{l}\text { Useful life } \\
\text { (years) }\end{array}\end{array}$ & $\begin{array}{l}\text { Kind of } \\
\text { allowance }\end{array}$ & $\begin{array}{l}\text { Allowance } \\
\text { rate }\end{array}$ & Useful life & $\begin{array}{l}\text { Kind of } \\
\text { allowance }\end{array}$ & $\begin{array}{l}\text { Allowance } \\
\text { rate }\end{array}$ & Useful life & \\
\hline Australia & SL & 2.5 & 40 & SL & 5 & 20 & DB & 28.57 & ufd & Weighted average \\
\hline Cambodia & SL & 5 & 20 & SL & 10 & 10 & DB & 20 & ufd & Weighted average \\
\hline China & SL & 5 & 20 & SL & 10 & 10 & SL & 10 & 10 & Weighted average \\
\hline Hong Kong & SL & $\begin{array}{l}4+20 \% \\
\text { initially }\end{array}$ & 20 & SL & 100 & 1 & DB & $\begin{array}{l}20+60 \\
\text { initially }\end{array}$ & ufd & Weighted average \\
\hline India & DB & 10 & ufd & DB & 25 & ufd & DB & 15 & ufd & Weighted average \\
\hline Indonesia & SL & 5 & 20 & DB & 12.5 & ufd & DB & 12.5 & ufd & Weighted average \\
\hline Japan & SL & 2.6316 & 38 & SL & 12.5 & 8 & DB & 25 & 10 & Weighted average \\
\hline Laos & SL & 2 & 50 & SL & 50 & 2 & SL & 20 & 5 & Weighted average \\
\hline Malaysia & SL & $\begin{array}{l}3+10 \\
\text { initially }\end{array}$ & 30 & SL & 20 & 5 & SL & $\begin{array}{l}14+20 \\
\text { initially }\end{array}$ & 6 & Weighted average \\
\hline Mongolia & SL & 2.5 & 40 & SL & 10 & 10 & SL & 10 & 10 & Weighted average \\
\hline Myanmar & SL & $15+3 *$ & & SL & 10 & 10 & SL & 10 & 10 & LIFO \\
\hline New Zealand & Useful life & f 100 years & & SL & 10 & 10 & DB & 13 & 15 & Weighted average \\
\hline Philippines & SYD & var & 30 & SYD & var & 10 & SYD & var & 7 & Weighted average \\
\hline Russia & SL & $10+3.1 *$ & 30 & SL & 10 & 10 & DB & $\begin{array}{l}33.33+30 \\
\text { initially }\end{array}$ & 2 & LIFO \\
\hline Singapore & - & - & - & - & - & - & SL & 33.33 & 3 & Weighted average \\
\hline South Korea & SL & 2.5 & 40 & SL & 10 & 10 & DB & 45.1 & ufd & LIFO \\
\hline Taiwan & DB & 4.5 & 50 & SL & 10 & 10 & SL & 14.2857 & 7 & LIFO \\
\hline Thailand & SL & 5 & 20 & SYD & var & 10 & SYD & var & 7 & LIFO \\
\hline
\end{tabular}




\begin{tabular}{|c|c|c|c|c|c|c|c|c|c|c|}
\hline Vietnam & SL & 3.3333 & 30 & SL & 10 & 10 & SL & 14.2857 & 7 & LIFO \\
\hline Germany & SL & 3 & 33.3333 & SL & 20 & 5 & SL & 14.2857 & 7 & LIFO \\
\hline USA & SL & $\begin{array}{l}2.46+ \\
2.56+ \\
0.11^{* *}\end{array}$ & 30 & SL & 6.6667 & 15 & DB & $\begin{array}{l}14.29+ \\
24.49 * * *\end{array}$ & 8 & LIFO \\
\hline
\end{tabular}

Source: IBFD Tax Reasearch Platform.

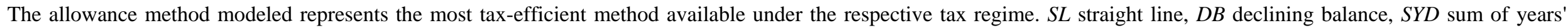

digit, var varying depreciation rate, ufd until fully depreciated, LIFO last-in-first-out

* 15\% (10\%) initial deprecation allowance in year of construction and 3\% (3.1\%) annually afterwards.

** $2.46 \%$ in year $1,2.56 \%$ for 38 years plus 0.11 in year 30 .

*** $14.29 \%$ in year $1,24.49 \%$ for 6 years plus final write-off in year 8 .

Table A5 - Effective average tax rates for domestic investments and cross-border investments by a German, Singaporean and US parent company

\begin{tabular}{lllll}
\hline \multirow{2}{*}{ Jurisdiction } & Domestic investment & \multicolumn{2}{c}{ Cross-border investments } \\
\cline { 3 - 5 } & & German parent company & $\begin{array}{l}\text { Singaporean parent } \\
\text { company }\end{array}$ & US parent company \\
\hline Australia & $28.6 \%$ & $38.6 \%$ & $38.7 \%$ & $32.3 \%$ \\
Cambodia & $18.4 \%$ & $29.4 \%$ & $29.3 \%$ & $30.7 \%$ \\
China & $23.9 \%$ & $31.5 \%$ & $28.4 \%$ & $31.8 \%$ \\
Hong Kong & $10.6 \%$ & $12.1 \%$ & $11.9 \%$ & $29.1 \%$ \\
India & $40.4 \%$ & $42.9 \%$ & $43.2 \%$ & $41.4 \%$ \\
Indonesia & $23.9 \%$ & $31.6 \%$ & $31.6 \%$ & $31.9 \%$ \\
Japan & $37.5 \%$ & $43.6 \%$ & $41.4 \%$ & $37.1 \%$ \\
Laos & $21.1 \%$ & $29.0 \%$ & $29.0 \%$ & $30.1 \%$ \\
Malaysia & $21.9 \%$ & $23.4 \%$ & $23.4 \%$ & $30.1 \%$
\end{tabular}




\begin{tabular}{lllll} 
Mongolia & $24.5 \%$ & $28.9 \%$ & $29.0 \%$ & $36.5 \%$ \\
Myanmar & $23.0 \%$ & $24.4 \%$ & $24.4 \%$ & $31.0 \%$ \\
New Zealand & $27.3 \%$ & $37.5 \%$ & $31.7 \%$ & $32.6 \%$ \\
Philippines & $30.4 \%$ & $37.3 \%$ & $40.3 \%$ & $38.4 \%$ \\
Russia & $19.1 \%$ & $24.0 \%$ & $23.9 \%$ & $31.3 \%$ \\
Singapore & $18.6 \%$ & $20.1 \%$ & $18.0 \%$ & $32.9 \%$ \\
South Korea & $21.8 \%$ & $26.5 \%$ & $29.7 \%$ & $30.6 \%$ \\
Taiwan & $14.9 \%$ & $25.3 \%$ & $32.6 \%$ & $33.3 \%$ \\
Thailand & $18.3 \%$ & $26.6 \%$ & $26.5 \%$ & $30.7 \%$ \\
Vietnam & $20.0 \%$ & $21.4 \%$ & $21.4 \%$ & $30.7 \%$ \\
\hline Source: Own calculations. & &
\end{tabular}


Table A6 - Withholding tax rates on dividends and interests paid to Germany, Singapore and the US

\begin{tabular}{lllllll}
\hline \multirow{2}{*}{ Subsidiary } & \multicolumn{2}{l}{ German Parent Company } & \multicolumn{2}{l}{ Singaporean Parent Company } & \multicolumn{2}{l}{ US Parent Company } \\
\cline { 2 - 7 } & Dividends & Interest & Dividends & Interest & Dividends & Interest \\
\hline Australia & $15 \%$ & $10 \%$ & $15 \%$ & $10 \%$ & - & $10 \%$ \\
Cambodia & $14 \%$ & $14 \%$ & $14 \%$ & $14 \%$ & $14 \%$ & $14 \%$ \\
China & $10 \%$ & $10 \%$ & $5 \%$ & $10 \%$ & $10 \%$ & $10 \%$ \\
Hong Kong & - & - & - & - & - & - \\
India & - & $10 \%$ & - & $15 \%$ & - & $15 \%$ \\
Indonesia & $10 \%$ & $10 \%$ & $10 \%$ & $10 \%$ & $10 \%$ & $10 \%$ \\
Japan & $10 \%$ & $10 \%$ & $5 \%$ & $10 \%$ & - & $10 \%$ \\
Laos & $10 \%$ & $10 \%$ & $10 \%$ & $10 \%$ & $10 \%$ & $10 \%$ \\
Malaysia & - & $10 \%$ & - & $10 \%$ & - & $15 \%$ \\
Mongolia & $5 \%$ & $10 \%$ & $5 \%$ & $10 \%$ & $20 \%$ & $20 \%$ \\
Myanmar & - & $15 \%$ & - & $10 \%$ & - & $15 \%$ \\
New Zealand & $15 \%$ & $10 \%$ & $5 \%$ & $10 \%$ & - & $10 \%$ \\
Philippines & $10 \%$ & $15 \%$ & $15 \%$ & $15 \%$ & $15 \%$ & $15 \%$ \\
Russia & $5 \%$ & - & $5 \%$ & $8 \%$ & $5 \%$ & - \\
Singapore & - & $8 \%$ & - & - & - & $15 \%$ \\
South Korea & $5 \%$ & $10 \%$ & $10 \%$ & $12 \%$ & $10 \%$ & $10 \%$ \\
Taiwan & $10 \%$ & $10 \%$ & $20 \%$ & $20 \%$ & $20 \%$ & $20 \%$ \\
Thailand & $10 \%$ & $15 \%$ & $10 \%$ & $15 \%$ & $10 \%$ & $15 \%$ \\
Vietnam & - & $10 \%$ & $5 \%$ & $10 \%$ & - & \\
\hline Source: IBFD Tax Research Platform & & & & & \\
\end{tabular}

Source: IBFD Tax Research Platform. 
Table A7 - Targets of tax incentives in the Asia-Pacific region by jurisdiction

\begin{tabular}{|c|c|c|c|c|c|c|c|c|c|}
\hline Jurisdiction & $\mathbf{R} \& \mathbf{D}$ & $\begin{array}{l}\text { Environmental } \\
\text { Protection }\end{array}$ & $\begin{array}{l}\text { Employment \& } \\
\text { Vocational Training }\end{array}$ & $\begin{array}{l}\text { High } \\
\text { Technology }\end{array}$ & Headquarter & Regional & $\begin{array}{l}\text { Infrastructure } \\
\text { Development }\end{array}$ & Export & Import \\
\hline Australia & $\mathrm{x}$ & $\mathrm{x}$ & $\mathrm{x}$ & & $\mathrm{x}$ & & & & \\
\hline Cambodia & & & & & & & $\mathrm{x}$ & $\mathrm{x}$ & $\mathrm{x}$ \\
\hline China & $\mathrm{x}$ & $\mathrm{x}$ & & $\mathrm{x}$ & & $\mathrm{x}$ & $\mathrm{x}$ & & \\
\hline Hong Kong & & $\mathrm{x}$ & & & & & & & \\
\hline India & & & $\mathrm{x}$ & & & $\mathrm{x}$ & $\mathrm{x}$ & $\mathrm{x}$ & \\
\hline Indonesia & & & & & & $\mathrm{x}$ & $\mathrm{x}$ & $\mathrm{x}$ & $\mathrm{x}$ \\
\hline Japan & $\mathrm{x}$ & $\mathrm{x}$ & $\mathrm{x}$ & & & & & & \\
\hline Laos & $\mathrm{x}$ & & $\mathrm{x}$ & & & $\mathrm{x}$ & & $\mathrm{x}$ & \\
\hline Malaysia & $\mathrm{x}$ & $\mathrm{x}$ & $\mathrm{x}$ & $\mathrm{x}$ & $\mathrm{x}$ & $\mathrm{x}$ & $\mathrm{x}$ & $\mathrm{x}$ & \\
\hline Mongolia & & & & & & & $\mathrm{x}$ & & \\
\hline Myanmar & & & & & & $\mathrm{x}$ & & $\mathrm{x}$ & $\mathrm{x}$ \\
\hline New Zealand & $\mathrm{x}$ & & & & & & & & \\
\hline Philippines & $\mathrm{x}$ & & $\mathrm{x}$ & & $\mathrm{x}$ & $\mathrm{x}$ & $\mathrm{x}$ & $\mathrm{x}$ & \\
\hline Russia & $\mathrm{x}$ & $\mathrm{x}$ & & & & $\mathrm{x}$ & & & \\
\hline Singapore & $\mathrm{x}$ & $\mathrm{x}$ & & $\mathrm{x}$ & $\mathrm{x}$ & & & & \\
\hline South Korea & & & $\mathrm{x}$ & $\mathrm{x}$ & & & & & \\
\hline Taiwan & $\mathrm{x}$ & & & & & & & & \\
\hline Thailand & & $\mathrm{x}$ & & $\mathrm{x}$ & $\mathrm{x}$ & $\mathrm{x}$ & $\mathrm{x}$ & $\mathrm{x}$ & $\mathrm{x}$ \\
\hline Vietnam & & & $\mathrm{x}$ & $\mathrm{x}$ & & $\mathrm{x}$ & $\mathrm{x}$ & & $\mathrm{x}$ \\
\hline
\end{tabular}


Table A8 - Effective average tax rates of investments eligible for tax incentives

\begin{tabular}{lllll}
\hline Jurisdiction & $\begin{array}{l}\text { Incentive resulting in } \\
\text { lowest tax burden }\end{array}$ & Regional incentive & $\begin{array}{l}\text { High technology } \\
\text { incentive }\end{array}$ & $\begin{array}{l}\text { EATR without } \\
\text { incentive }\end{array}$ \\
\hline Cambodia & $12.2 \%$ & $18.4 \%$ & $18.4 \%$ & $18.4 \%$ \\
China & $11.7 \%$ & $11.7 \%$ & $14.6 \%$ & $23.9 \%$ \\
Hong Kong & $10.3 \%$ & $10.6 \%$ & $10.6 \%$ & $10.6 \%$ \\
India & $22.6 \%$ & $25.5 \%$ & $40.4 \%$ & $40.4 \%$ \\
Indonesia & $11.4 \%$ & $22.1 \%$ & $23.9 \%$ & $23.9 \%$ \\
Laos & $10.6 \%$ & $10.6 \%$ & $21.1 \%$ & $21.1 \%$ \\
Malaysia & $15.6 \%$ & $15.6 \%$ & $15.6 \%$ & $21.9 \%$ \\
Mongolia & $19.4 \%$ & $24.5 \%$ & $24.5 \%$ & $24.5 \%$ \\
Myanmar & $12.9 \%$ & $12.9 \%$ & $23.0 \%$ & $23.0 \%$ \\
Philippines & $22.0 \%$ & $22.0 \%$ & $30.4 \%$ & $30.4 \%$ \\
Russia & $17.8 \%$ & $17.8 \%$ & $19.1 \%$ & $19.1 \%$ \\
Singapore & $7.0 \%$ & $18.6 \%$ & $7.0 \%$ & $18.6 \%$ \\
South Korea & $14.5 \%$ & $21.8 \%$ & $14.5 \%$ & $21.8 \%$ \\
Thailand & $9.6 \%$ & $9.6 \%$ & $11.0 \%$ & $18.3 \%$ \\
Vietnam & $9.2 \%$ & $9.2 \%$ & $9.2 \%$ & $20.0 \%$ \\
\hline So & & & \\
\hline
\end{tabular}

Source: Own calculations. See Figure 6 and Figure 7.

Table A9 - Comparison of effective average tax rates on outbound investments by a Singaporean headquarter

\begin{tabular}{llll}
\hline Jurisdiction & $\begin{array}{l}\text { EATR standard cross- } \\
\text { border investment }\end{array}$ & EATR RHQ award & EATR IHQ award \\
\hline Australia & $38.73 \%$ & $38.68 \%$ & $38.43 \%$ \\
Cambodia & $29.34 \%$ & $29.29 \%$ & $29.50 \%$ \\
China & $28.43 \%$ & $28.39 \%$ & $28.14 \%$ \\
Hong Kong & $11.92 \%$ & $11.88 \%$ & $10.96 \%$ \\
India & $43.22 \%$ & $43.18 \%$ & $43.51 \%$ \\
Indonesia & $31.62 \%$ & $31.57 \%$ & $31.32 \%$ \\
Japan & $41.41 \%$ & $41.36 \%$ & $41.11 \%$ \\
Laos & $29.02 \%$ & $28.97 \%$ & $28.72 \%$ \\
Malaysia & $23.36 \%$ & $23.32 \%$ & $23.07 \%$ \\
Mongolia & $28.99 \%$ & $28.95 \%$ & $28.69 \%$ \\
Myanmar & $24.40 \%$ & $24.36 \%$ & $24.11 \%$ \\
New Zealand & $31.68 \%$ & $31.64 \%$ & $31.38 \%$ \\
Philippines & $40.27 \%$ & $40.23 \%$ & $40.56 \%$
\end{tabular}




\begin{tabular}{llll} 
Russia & $23.91 \%$ & $23.87 \%$ & $23.32 \%$ \\
South Korea & $29.70 \%$ & $29.66 \%$ & $29.41 \%$ \\
Taiwan & $32.57 \%$ & $32.60 \%$ & $33.09 \%$ \\
Thailand & $26.53 \%$ & $26.48 \%$ & $26.81 \%$ \\
Vietnam & $21.41 \%$ & $21.37 \%$ & $21.12 \%$ \\
\hline
\end{tabular}

Source: Own calculations. See Figure 8. 